\title{
Are there alternatives to bankruptcy? A study of small business distress in Spain
}

\author{
Miguel García-Posada • Juan S. Mora-Sanguinetti
}

Received: 31 May 2013 / Accepted: 21 April 2014 / Published online: 20 May 2014

(C) The Author(s) 2014. This article is published with open access at SpringerLink.com

\begin{abstract}
Small businesses, the majority of Spanish firms, rarely file for formal bankruptcy when dealing with financial distress. This is why business bankruptcy rates in Spain are among the lowest in the world, even during the current economic crisis. To explain this fact we present the following hypothesis. Filing for bankruptcy in Spain is very costly for both small firms and their creditors. Due to this, the capital structure of micro firms is biased towards mortgage loans, as it allows them to avoid bankruptcy by carrying out debt enforcement via mortgage foreclosures, which are cheaper procedures than bankruptcy, in case of financial distress. The empirical tests of our hypothesis consist of comparing the observed choices (choice of capital structure, choice between bankruptcy and mortgage) of Spanish firms with those of firms from countries (France and the UK) where their bankruptcy systems are more efficient and their laws do not incentivise them to bias their capital structure towards mortgage loans. Our findings corroborate the proposed hypothesis. As bankruptcy procedures and mortgage foreclosures are not perfect substitutes-i.e., they do not suit well the
\end{abstract}

We are grateful to Brindusa Anghel, Jens Arnold, Francisco Cabrillo, Mercedes Castillo, Julio Cáceres-Delpiano, Marco Celentani, Juan J. Dolado, Andrés Fuentes, Fernando Gómez, María Gutiérrez, Paloma López-García, Matilde Machado, Ronan McCrea, Ricardo Mora, Thomas Molin, Alexandros Ragoussis, Cyrille Schwellnus, Alexandre Trémolière, Stefan van Hemmen, Raquel Vegas and to two anonymous referees for their useful comments and suggestions. We thank as well seminar participants at Harvard University, the OECD, the Banco de España and Universidad Carlos III de Madrid, as well as participants and reviewers at the II Annual Conference of the Spanish Association of Law and Economics and at the ENTER Jamboree. We are also grateful to Arnaud Atoch, Marcos Marchetti and Adolfo Mendieta for technical assistance and computational advice. This work was partly carried out while Juan S. Mora-Sanguinetti was working at the Economics Department of the OECD. The views expressed in the paper are the responsibility of the authors and, therefore, do not necessarily coincide with those of the Banco de España, the Eurosystem or the OECD.

M. García-Posada $(\varangle) \cdot$ J. S. Mora-Sanguinetti

Banco de España, Eurosystem, Madrid, Spain

e-mail: miguel.garcia-posada@bde.es 
same type of firms- the underutilization of one of them-reflected in low bankruptcy rates- may lead to efficiency losses.

Keywords Bankruptcy · Mortgage $\cdot$ Insolvency

JEL Classification $\mathrm{G} 33 \cdot \mathrm{G} 21 \cdot \mathrm{K} 0$

\section{Introduction}

Business bankruptcy rates (ratio of the number of business bankruptcy filings to the number of business exits) in Spain are among the lowest in the world, which means that Spanish firms rarely enter a formal bankruptcy procedure. The goal of this paper is to explain this empirical observation, which may imply that economic agents regard the system as inefficient and try to deal with financial distress in alternative ways. ${ }^{1}$ For that purpose we employ a large sample of Spanish, French and UK firms, finding that small businesses in Spain, unlike their European counterparts, rely on mortgage foreclosures $^{2}$ as the main alternative to bankruptcy proceedings.

According to Table 1 Spain had the second lowest bankruptcy rate out of 26 countries, including both high-income and emerging economies, in 2006. An even more striking observation is the difference in the orders of magnitude between Spain and other developed economies: for instance, while there were around 29 bankruptcies per 100 firm exits in France and 16 in the UK, there were 0.3 in Spain. Only the deep economic crisis that Spain is currently experiencing has modestly increased the number of bankruptcy filings, but the Spanish bankruptcy rate was still one of the lowest in the world in 2010 (see Table 1).

In contrast with the low incidence of business bankruptcies, business mortgage foreclosures have soared during the crisis. While around 8,000 firms filed for bankruptcy in 2012, there were nearly 26,000 business mortgage foreclosures ${ }^{3}$ in the same year. Moreover, the latter figure must be considered a lower bound, since small business owners may finance their firms with loans secured on their homes (Berkowitz and

\footnotetext{
1 Following Djankov et al. (2008), by "bankruptcy" we mean a legal procedure that imposes court supervision over the financial affairs of a firm or individual that has broken its promises to creditors or honours them with difficulty, and whose possible outcomes are reorganisation or liquidation. By "financial distress" we mean a situation in which a firm is close to default and it needs to take corrective action, such a selling major assets, merging with another firm or filing for bankruptcy (Ross et al. 2005). See Appendix A for a discussion on the legal terms used in this paper.

2 A foreclosure is "a debt enforcement procedure aimed at recovering the money owed to secured creditors" (Djankov et al. 2008). There are different types of foreclosures depending on which collateral can be repossessed using a single execution procedure. Since this paper concentrates on the analysis of small firms and entrepreneurs, and land and buildings are the main assets that can be pledged as collateral by them, we will focus on "mortgage over land and buildings" foreclosures (henceforth, mortgage foreclosures). In other words, by "mortgage" we will mean a loan secured by land and buildings, and not by other types of collateral. This is a necessary remark because there are other types of mortgages in some legal systems such as the British one. For more details see Appendix A.

3 Source: Consejo General del Poder Judicial (2012) and Registradores de España (2012).
} 
Table 1 Business bankruptcy rates around the world
Business bankruptcy rates are computed as the ratio of the number of business bankruptcy filings to the number of business exits, in \%. They include the figures for individual entrepreneurs, except in the UK, where they only represent companies. To enhance comparability across countries, we do not take into account exits from industries with high public sector presence (education, health, social and personal service activities). Source authors' computations with data from Euler Hermes (2007, 2011), Eurostat, OECD and national sources

\begin{tabular}{|c|c|c|}
\hline Country & $\begin{array}{l}\text { Business bankruptcy } \\
\text { rate (2006) }\end{array}$ & $\begin{array}{l}\text { Business bankruptcy } \\
\text { rate (2010) }\end{array}$ \\
\hline Poland & 0.3 & 0.3 \\
\hline Spain & 0.4 & 1.7 \\
\hline South Korea & 0.6 & 0.2 \\
\hline Greece & 1.1 & - \\
\hline Czech Republic & 1.2 & 2.0 \\
\hline Portugal & 1.5 & 2.4 \\
\hline Singapore & 1.5 & 1.0 \\
\hline Brazil & 5.3 & 0.6 \\
\hline Ireland & 3.2 & 4.9 \\
\hline Italy & 4.0 & 3.7 \\
\hline Slovak Republic & 4.5 & 2.8 \\
\hline USA & 4.8 & 3.9 \\
\hline Canada & 9.2 & 7.9 \\
\hline Denmark & 9.5 & 24.1 \\
\hline Finland & 11.7 & 10.8 \\
\hline Germany & 12.2 & 13.6 \\
\hline Netherlands & 12.4 & 13.7 \\
\hline UK & 16.2 & 14.0 \\
\hline Hungary & 16.8 & 29.3 \\
\hline Sweden & 17.9 & 17.9 \\
\hline Norway & 19.6 & 24.3 \\
\hline France & 28.5 & 31.3 \\
\hline Austria & 28.8 & 32.3 \\
\hline Belgium & 30.0 & 51.6 \\
\hline Luxembourg & 30.6 & 43.5 \\
\hline Switzerland & 43.6 & - \\
\hline Australia & - & 4.9 \\
\hline Estonia & - & 13.8 \\
\hline Latvia & - & 14.6 \\
\hline Lithuania & - & 2.7 \\
\hline Hong Kong & & 0.9 \\
\hline
\end{tabular}

White 2004) but, if lenders repossess the collateral, they will be reflected as residential foreclosures in the official statistics.

However, the use of bankruptcy procedures by Spanish businesses varies widely depending on the size of the distressed firms, as shown in Fig. 1. While the rates of micro firms (businesses with less than 10 employees) were around $0.15 \%$ in 2006 and they have just reached $1.3 \%$ during the economic crisis, those of nonmicro firms were $10.4 \%$ in 2006 and they have increased up to $90 \%$ during the crisis, in line with the aggregate rates of developed countries. Since micro firms 


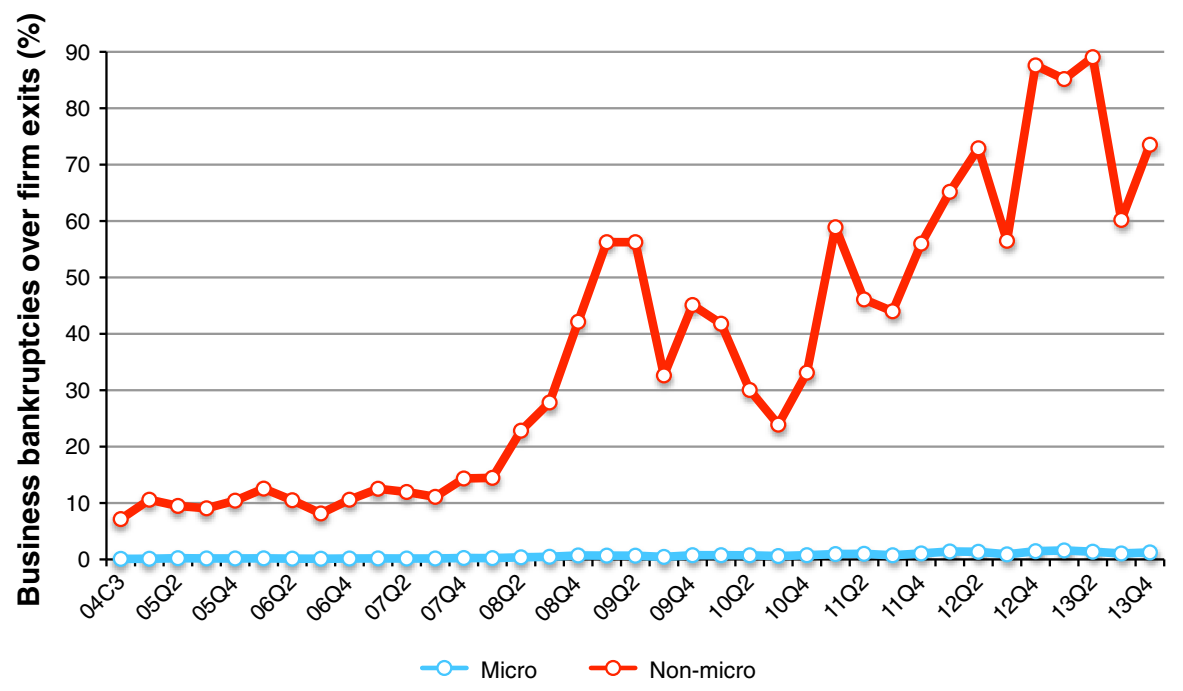

Fig. 1 Bankruptcy rates by size in Spain. Data are quaterly except for the first period 04C3 (last 4 months of 2004). Rates are annualized. Source: authors' calculations on data from the Spanish National Statistics Institute. Size is measured in terms of employees. Micro: [0,9], small: [10,49], medium and large: $>50$. Non-micro: $>9$

account for more than the $95 \%$ of firms in Spain, ${ }^{4}$ they are the key drivers of the low bankruptcy rate of Spanish companies. They are also very important in terms of economic activity: they accounted for $51 \%$ of total employment and $28 \%$ of total value added before the economic crisis and they currently account for 39 and $25 \%$, respectively. ${ }^{5}$ Finally, although the available evidence is rather limited, Spanish micro firms seem to file for bankruptcy much less than some of their European counterparts: in 2006, the bankruptcy rates for self-employed and micro enterprises were 0.01 and $0.15 \%$, respectively, in Spain, while those in France were 11.1 and $23 \%,{ }^{6}$ and the bankruptcy rate for self-employed in the UK exceeded $16.2 \% .^{7}$

Spanish micro firms also have other distinct characteristics. They hold, by far, the largest proportion of mortgage loans over financial debt, as shown in Fig. 2. Filing for bankruptcy is especially unattractive for them because a significant proportion of the bankruptcy costs are fixed (Van Hemmen 2011). ${ }^{8}$ Personal bankruptcy may apply to many of those firms regardless of their legal form, because the distinction between limited and unlimited liability may be blurred for them, partly because lenders

\footnotetext{
4 Source: Central Business Register, National Statistics Institute of Spain.

5 Sources: Observatory of European SMEs (2003) and authors' computations from Eurostat.

6 Sources: Instituto Nacional de Estadística, Altares (2011), Eurostat.

7 Figures on bankruptcy filings for self-employed are only available for England and Wales, so the computed bankruptcy rate (176) is a lower bound of that for the UK.

8 Compensation of the insolvency administrators, lawyers' fees, etc.
} 


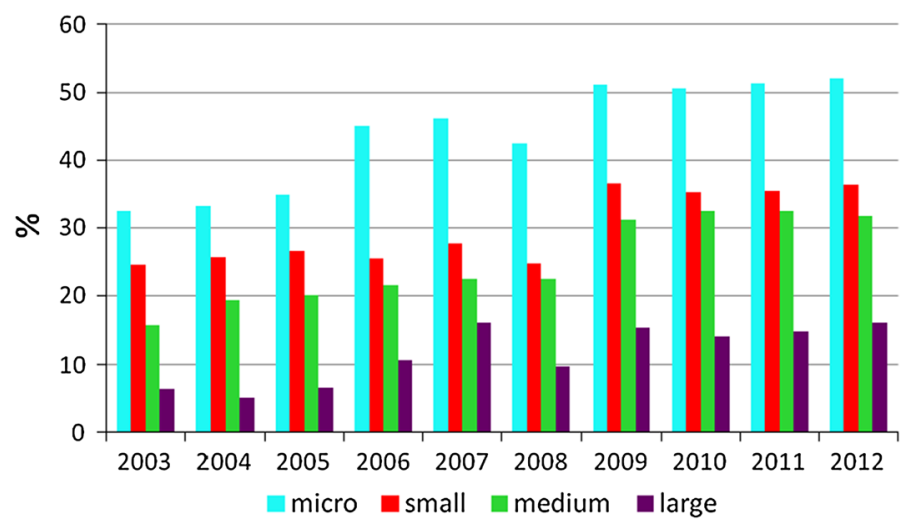

Fig. $2 \%$ Mortgage loans over bank debt by business size in Spain. Source: Authors' elaboration with data from the Central Credit Register and the Central Balance Sheet Data Office, Banco de España

require personal guarantees or security in the form of a mortgage on the owner's home (Berkowitz and White 2004).

Consistent with those stylized facts, our hypothesis on the low business bankruptcy rates in Spain is the following. Filing for bankruptcy in Spain is very costly for both small firms and their creditors. Due to this, the capital structure of micro firms is biased towards mortgage loans (i.e., loans secured on land and buildings). Having this capital structure allows them to avoid bankruptcy by carrying out debt enforcement via mortgage foreclosures, ${ }^{9}$ which are cheaper procedures than bankruptcy, in case of financial distress.

In order to test this hypothesis the optimal identification strategy would be to analyse the impact of substantial changes in the Spanish bankruptcy law in both bankruptcy rates and firms' capital structure. The current bankruptcy code entered into force in 2004 after a major legislative reform. But it seems that the de facto insolvency framework barely changed because the performance of bankruptcy proceedings did not seem to substantially improve (Gutiérrez 2005; Van Hemmen 2004), bankruptcy rates did not increase after the introduction of the new code and it seems that firms' capital and asset structures have not changed either (Celentani et al. 2010).

By contrast, our identification strategy relies on cross-country comparisons. Specifically, we compare the observed choices (choice of capital structure, choice between bankruptcy and mortgage) of Spanish firms with those of firms from countries where their bankruptcy systems are more efficient and their laws do not incentivise them to bias their capital structure towards mortgage loans. France and the UK are chosen as the comparison group because their bankruptcy rates are much higher than the Spanish ones and because of the specific features of their insolvency frameworks. ${ }^{10}$

\footnotetext{
9 Mortgage creditors can also enforce their claims inside a bankruptcy procedure, as any other creditors. Throughout this paper we will use the term "mortgage foreclosure" when we mean debt enforcement outside bankruptcy.

10 We must exclude other potentially interesting examples (e.g. Germany and the US) due data constraints. Our data come from the office of the Registrar of Companies of each country, but only large firms have the
} 
Our findings corroborate the proposed hypothesis. First, there is a positive and strong correlation between the ex-ante probability of default and the ratio of tangible fixed assets (the assets that can be pledged as mortgage collateral) to financial debt in the case of Spanish micro firms, suggesting that firms with risky business models bias their capital structure towards mortgage loans to avoid filing for bankruptcy in the event of default. Second, a higher proportion of tangible fixed assets over financial debt significantly decrease the probability of being in bankruptcy among Spanish micro firms in financial distress. By contrast, these two relations do not hold either for Spanish larger businesses or for firms from the other two countries.

Finally, we must stress the importance of the research question. The model of García-Posada (2013) predicts that, in the context of the Spanish insolvency framework, there is a positive relation between bankruptcy rates and welfare. The intuition is that low bankruptcy rates and low welfare are the outcome of an institutional design characterised by the low efficiency and low creditor protection of the bankruptcy system relative to those of an alternative insolvency institution, the mortgage system. In that context, firms and their creditors avoid filing for bankruptcy by heavily relying on mortgage collateral, which can be repossessed and liquidated in the event of default. The problem is that the mortgage system is not well suited for some firms, which need to bias their asset structure to have enough collateral, with the ensuing productive inefficiencies. Those firms would be better off if they had access to a bankruptcy system that worked relatively well. In other words, as the bankruptcy and mortgage systems are imperfect substitutes, the equilibrium in which only mortgage is widely used (reflected in low bankruptcy rates) is Pareto dominated by the equilibrium in which agents can choose between the two insolvency institutions (reflected in higher bankruptcy rates). His analysis also predicts that bankruptcy will be unfeasible for the smallest firms in the economy as long as some of the bankruptcy costs are fixed. As some of those firms will have to overinvest in capital assets to sign their contracts under mortgage, they will incur in productive inefficiencies. If the absence of a well-functioning bankruptcy system for those firms also reduces their growth opportunities-e.g., by hampering access to unsecured lending such as venture capital-then the current insolvency framework may help explain the firm size distribution and the low aggregate productivity of the Spanish economy. This is consistent with the evidence of Fabbri (2010) in Spain, who finds that lengthy bankruptcy procedures decrease firm size and raise funding costs and with that of Ponticelli (2012) in Brazil, who shows that congestion in bankruptcy courts substantially reduces firmlevel investment and productivity.

The rest of the paper is structured as follows. Section 2 provides a brief literature overview and discusses the paper's main contributions. Section 3 discusses some key features of the insolvency framework of Spain, France and the UK Sect. 4 focuses on data sources and sample selection criteria. Section 5 explains the empirical testing of the hypothesis. Section 6 concludes. Appendix A provides a description of the

Footnote 10 continued

legal obligation to register their annual accounts in Germany. In the case of the US, the available data is at plant-level, while the decision to file for bankruptcy is made at firm-level. 
main legal concepts used in this paper and Appendix B contains some robustness analyses.

\section{Contribution and related literature}

This paper is mainly related to the works of Morrison (2008, 2009), and Celentani et al. (2010, 2012). Morrison (2008, 2009) studied why US small distressed firmsdefined as those with 500 or fewer employees - rarely file for bankruptcy. He argued that there are cheaper procedures for these firms, such as assignments for the benefit of creditors, ${ }^{11}$ bulk sales, ${ }^{12}$ foreclosures and private workouts. Their implementation, however, require that neither the debtor firm nor the creditors' file for bankruptcy. They also face, unlike the bankruptcy system, major coordination and asymmetric information problems that may hamper their use. Thus he identified the conditions under which these problems are not very important so those procedures can be implemented: small firms, with simple capital structures (i.e., low number of secured creditors) and with close and trustworthy relationships with their creditors are likely to avoid filing for bankruptcy. This paper applies a similar reasoning to the Spanish, British and French case: wherever there are cheaper alternatives to bankruptcy, the latter will only be used when parties don't reach an agreement, becoming the residual option.

Celentani et al. $(2010,2012)$ were the first that studied the low bankruptcy rates in Spain. They proposed an explanation that was not immediately contradicted by a number of aggregate stylized facts. Specifically, they used the theoretical prediction of Ayotte and Yun (2009), according to which low creditor protection and low judicial ability imply low bankruptcy rates, to conjecture a wide set of activities (leverage reduction, lenders' screening and monitoring, choice of projects that trade off return for lower risk and/or lower liquidation costs, use of mortgage collateral) in which firms and their creditors could engage to reduce the probability of bankruptcy. This paper focuses on one of their ideas, the use of mortgage foreclosures as an alternative to formal bankruptcy procedures. To the best of our knowledge, this is the first study that addresses the research question with firm-level data, which allows testing the hypothesis by means of econometric analyses.

\section{Insolvency frameworks}

In this section we will focus on the features of the insolvency frameworks of Spain, France and the UK related to our hypothesis, namely, the choice between bankruptcy procedures and mortgage foreclosures and the choice of firms' capital and asset structures. We will examine the incentives to file for bankruptcy of both the debtor firm and its creditors, as alternative procedures such as mortgage foreclosures can only take

\footnotetext{
11 In an assignment for the benefit of creditors, the business assigns its assets to a trustee, who auctions them off and distributes the proceeds to creditors.

12 In a bulk sale the debtor sells most or all of its business to a third party and distributes the proceeds to creditors.
} 
place if both parties refrain from filing. For a more thorough analysis of the insolvency frameworks see Celentani et al. (2010, 2012) and Davydenko and Franks (2008).

\subsection{Spain}

The Spanish bankruptcy system (Ley Concursal) only had, until very recently, an insolvency procedure, the concurso de acreedores (bankruptcy ${ }^{13}$ ), both for firms and individual debtors. ${ }^{14}$ Both the debtor and the creditors may initiate the proceedings.

Bankruptcy procedures are costly and lengthy, rendering them unappealing for both distressed firms and their creditors. The direct costs of bankruptcy are high, as those procedures are complex, uncertain, involve many creditors and face high information asymmetries between the company and its lenders, requiring a great deal of intervention by the court, insolvency administrators, lawyers, etc. According to the Doing Business estimates, those costs would account for a $15 \%$ of the firm's total assets. As a substantial part of those costs are fixed (Van Hemmen 2008), bankruptcy procedures are especially costly in the case of small firms. The median duration of a bankruptcy process ranged between 20 and 23 months ${ }^{15}$ (Van Hemmen 2008) before the economic crisis. The modest increase in the number of bankruptcy filings due to the crisis has congested the courts and lead to a dramatic increase in the length of the procedures, which ranged between 28 and 42 months in 2011 (Van Hemmen 2012). ${ }^{16}$ Finally, as the law does not provide any debt discharge for individuals ${ }^{17}$ and homestead exemptions are very low, individual debtors-including self-employed people and owners of small limited-liability firms that pledge personal guarantees to obtain funding for their businesses-have no incentives to file for bankruptcy.

Mortgage foreclosures are much cheaper and quicker than bankruptcy procedures, as they are quite standardised processes with a low degree of uncertainty about its final outcome. According to European Mortgage Federation (2007), their total costs are between the 5 and $15 \%$ of the price obtained in the auction of the collateral (the percentage decreases as the sale price increases), and their usual length is $7-9$ months. ${ }^{18}$

Hence, mortgage foreclosures are an attractive alternative to bankruptcy, especially in the case of small firms. But, to make possible that a firm and their creditors use the mortgage system in case of financial distress, the firm's capital structure must be biased towards mortgage loans and their asset structure must be biased towards assets_-such as land and buildings_- that can be pledged as mortgage collateral.

\footnotetext{
13 Read Appendix A for further clarifications on the translation of the legal terms of this paper.

14 In September 2013 the Spanish Parliament has approved some legal reforms that will create some sort of special bankruptcy regime for self-employed individuals. See Appendix A, Sect. A.6, for details.

1520 months for the so-called simplified procedure (concurso abreviado), 23 for the ordinary (concurso ordinario). See Appendix A for details.

16 Similar estimations are provided by the General Council of the Judicial Power (Consejo General del Poder Judicial 2011).

17 In other words, all the present and future income of the debtor must be used to pay back pre-bankruptcy debts.

18 Some of the legislative changes concerning the Spanish mortgage law (Ley Hipotecaria) introduced in 2013 may increase the length of mortgage foreclosures in the future (see Appendix A, Sect. 6 for details), but not in the period of study of this research.
} 


\subsection{France}

The redressement judiciaire (judicial reorganization) and the liquidation judiciaire (judicial liquidation) are the main insolvency procedures for corporations in France. As for personal bankruptcy, which may apply to both consumer and entrepreneurs, there are two different procedures: the plan de redressement (reorganization plan) and the procedure de rétablissement personnel (procedure of personal recovery). The debtor, creditors, the public prosecutor and the court itself may initiate the proceedings.

Bankruptcy procedures are relatively cost-effective. According to the Doing Business estimates, the direct costs would account for a $9 \%$ of the firm's total assets and the average duration in 2007 was 14.2 months (Ministère de la Justice 2010). Moreover, self-employed and small business owners may have incentives to file for personal bankruptcy as they may benefit from debt discharge in some circumstances. ${ }^{19}$

Another characteristic of the bankruptcy system is the high dilution that mortgage credit suffers inside bankruptcy (Davydenko and Franks 2008). First, there is an automatic stay for secured creditors until the end of the procedure. Second, bankruptcy courts tend to sell the assets below their potential market prices, as they are not obliged to sell the assets to the highest bidder, but they can sell the whole company to a lower bidder that commits to preserve employment, as creditors' approval is not required for the sale of their collateral. Third, the state places its own claims and those of employees first in priority when the collateral is sold.

In that context, mortgage creditors would like to enforce their claims outside bankruptcy via mortgage foreclosures, but they are quite slow and expensive. According to European Mortgage Federation (2007), their total costs are between the 10 and $12 \%$ of the price of allocation and their usual length is between 15 and 25 months. As a result, the response of creditors is to rely more on some types of collateral-such as personal guarantees and accounts receivable - that can be realised directly by secured creditors and are not diluted by preferential creditors. These collateral types are used more often than mortgage collateral (Davydenko and Franks 2008).

Hence, mortgage foreclosures are not an attractive alternative to bankruptcy and mortgage collateral is not a very appealing guarantee. As a consequence, we expect mortgage loans to have little weight in the firms' capital structure and the assets that can be pledged as mortgage collateral—such as land and buildings— to account for a low proportion of their total assets.

\section{$3.3 \mathrm{UK}$}

Although various corporate insolvency procedures coexist in the UK, administration is the most important one since the entry into force of the Enterprise Act $2002^{20}$ and

\footnotetext{
19 There is immediate debt discharge in the procedure de retablissement personnel. In the plan de redressement, although it mainly consists of a reorganisation plan, the judge may enforce a debt-restructuring schedule and he can also partly reduce the debts. For more details see Blazy et al. (2011).

20 The main insolvency procedure before the Enterprise Act 2002, administrative receivership, is normally characterised as a foreclosure, since it was a procedure for the enforcement of a security interest (a floating charge) covering all or nearly all the assets of the debtor firm, while administration is normally classified as a bankruptcy procedure (Djankov et al. 2008).
} 
bankruptcy is the most common procedure used by individuals. ${ }^{21}$ Both the debtor and the creditors may initiate the proceedings.

Bankruptcy procedures are quite cheap and fast. According to the Doing Business estimates, the direct costs would account for a $6 \%$ of the firm's total assets and their average duration would be $<1$ year (Armour and Hsu 2012; Frisby 2006). In the case of personal bankruptcy, debt discharge is allowed one year after the end of the procedure, providing incentives to small firms and self-employed to file for bankruptcy.

Another characteristic of the UK insolvency framework is the existence of floating charges. A floating charge is a security interest over a fund of a firm's changing assets that "floats" until it "crystallises" (converts) into a fixed charge, ${ }^{22}$ at which point the charge attaches to specific assets. The crystallisation can be triggered by a number of events, being one of them the borrower's default. There are two main differences between a floating charge and other security interests such as a mortgage. First, because the security "floats", the firm remains free to purchase and sell its assets. Second, the assets of the entire business can be pledged as collateral. Those characteristics grant high flexibility to the firm's asset structure and permit it not to be biased through certain types of assets such as land and buildings.

Mortgage foreclosures are neither significantly faster nor cheaper than bankruptcy procedures. According to European Mortgage Federation (2007) their usual length is between 8 and 12 months and their total costs are around $5 \%$. These facts, together with the existence of floating charges, lead us to expect a low incidence of foreclosures and a relatively low weight of mortgage loans (land and buildings) in firms' capital (asset) structures.

Table 2 summarises the main characteristics of the insolvency frameworks of Spain, France and the UK.

\section{Data}

The firm-level data come from the OECD-Orbis database, which is the result of the treatment of the commercial database Orbis by the OECD (Ribeiro et al. 2010; Ragoussis and Gonnard 2011). Orbis contains financial information on both private and publicly held companies around the world although coverage, especially of small firms, greatly varies across countries. Orbis also provides other non-financial information, such as year of incorporation, industry, legal form and status. Status is a variable that tells the legal and economic condition of the firm: for instance, if the company is active or it has ceased its operations and if it is undergoing a bankruptcy procedure or not. The data have, however, some important limitations. First, if a business shut down without filing for bankruptcy, the records do not indicate which alternative procedure the firm used. ${ }^{23}$ Second, the status is only observed at the moment in which the data are extracted from the database, i.e., no historical records are kept. Since the data

\footnotetext{
21 In the UK the term "bankruptcy" only applies to individuals, while insolvency is the term that applies to companies.

22 See Appendix A for an explanation of floating and fixed charges.

23 But it does indicate mergers, so we can exclude them from the analysis.
} 
Table 2 Insolvency frameworks in Spain, France and the UK

\begin{tabular}{|c|c|c|}
\hline & Bankruptcy & Mortgage \\
\hline \multicolumn{3}{|l|}{ Panel A: Spain } \\
\hline Duration (months) & $20-23$ & $7-9$ \\
\hline Cost (\% assets) & $15 \%$ & $5-15 \%$ \\
\hline Discharge for individual debtors? & No & No \\
\hline \multicolumn{3}{|l|}{ Panel B: France } \\
\hline Duration (months) & 14.2 & $15-25$ \\
\hline Cost (\% assets) & $9 \%$ & $10-12 \%$ \\
\hline Discharge for individual debtors? & Yes & No \\
\hline Other characteristics & $\begin{array}{l}\text { High dilution of mortgage } \\
\text { credit inside bankruptcy }\end{array}$ & \\
\hline \multicolumn{3}{|l|}{ Panel C: UK } \\
\hline Duration (months) & $<12$ & $8-12$ \\
\hline Cost (\% assets) & $6 \%$ & $5 \%$ \\
\hline Discharge for individual debtors? & Yes & No \\
\hline Other characteristics & Floating charge & \\
\hline
\end{tabular}

Sources: European Mortgage Federation (2007), Van Hemmen (2008), Ministère de la Justice (2010), Kindly check Armour and Hsu (2012) given in Table footnote not present in reference list, Frisby (2006), Doing Business Database

from Orbis were extracted in 2010 (December 31, 2010), we have the status of each company at that time. Finally, as Orbis is a commercial database, our sample may not be representative of the whole population. We address this potential criticism in Appendix B.

Regarding the sample selection, we use data on firms from three countries: Spain, France and the UK We only keep their financial data for 2008 because of two reasons. First, the main variable in all our analyses will be constructed using the information on status, which is only available for 2010. This makes panel data an unfeasible structure for the sample, since the variation in the main variable will happen across sections, but not across time. Second, because of the time lag in the submission of financial statements by firms, the Orbis database is characterised by a typical time lag of 2 years (Ribeiro et al. 2010), which implies that coverage (in number of companies with complete records) for 2009 and 2010 is very poor, leaving 2008 as the best choice. While this time gap could be problematic, it alleviates a simultaneity bias that may arise if the bankruptcy process or the alternative insolvency procedure affects the company's financials (e.g. a foreclosure on some of the firm assets or a debt haircut), as our regressors will be lagged twice. We also apply some filters to clean the data. We exclude state-owned companies, non-profit organisations and membership organisations. To avoid double-counting of information we eliminate all consolidated accounts for which unconsolidated information exists. Finally, we remove inconsistent observations $^{24}$ and extreme values. Our final sample has more than 560,000 firm-level observations.

$\overline{24}$ For instance, those that violate basic accounting rules. 
For the empirical analyses of this paper it is crucial to distinguish between financially distressed firms and non-distressed ones. While it is probably safe to assume that all firms under bankruptcy proceedings are distressed (rarely will a healthy business file a bankruptcy petition), for the rest of observations we proxy distressed businesses as those whose interest coverage ratio (EBITDA ${ }^{25}$ over interest expenses) is lower than 1 .

We then construct several variables. Bankruptcy is a dummy variable that equals 1 if the firm was bankrupt when the data were extracted (2010). To measure the probability of default we use the Altman's Z-Score (Altman 2000). ${ }^{26}$ As the Orbis database does not contain specific information on mortgage loans, we need to construct a proxy for the proportion of those loans on total debt. The proposed proxy is "Tangibility", which is computed as the ratio between tangible fixed assets (land, buildings, plant and machinery $)^{27}$ to financial debt, in percentage terms. Since tangible fixed assets are the only assets that can be used as mortgage collateral in Spain, we relate those assets with the debts they may secure. For robustness, we have carried out all this paper's analyses with an alternative proxy that includes trade credit, namely the ratio between tangible fixed assets to total debt, reaching very similar conclusions, which is not surprising given the high correlation between the two proxies. ${ }^{28}$

As controls, we use a dummy that equals 1 if the firm has limited liability, the firm's age, the firm's size — computed as the number of employees ${ }^{29}$ - and industry dummies. According to Berger and Udell (1995) and Petersen and Rajan (1994), firm's age captures the public reputation of the firm, since they find a negative relationship between firms' age and interest rate premium charged by banks. Davydenko and Franks (2008) interpret age as a proxy for information asymmetries between a firm and its lenders, since they find negative impact of age on the probability of filing for bankruptcy (vis-à-vis using out-court procedures). Age may also capture coordination costs, as older firms are more likely to maintain multiple bank relationships (Hernández-Cánovas and Köeter-Kant 2008). With respect to firm's size, small firms may file less for bankruptcy if a substantial proportion of the bankruptcy costs are fixed (Morrison 2008) or if personal insolvency laws are very severe, although the relationship between size and bankruptcy need not be linear because very large firms

\footnotetext{
25 Earnings before interests, taxes, depreciation and amortization.

26 The Z-Score has several versions depending on the type of firms. The one used in this paper is for non-listed firms that do not necessarily belong to the manufacturing sector. The exact formula is: $\mathrm{Z}=$ $6.56 \mathrm{X} 1+3.26 \mathrm{X} 2+6.72 \mathrm{X} 3+1.05 \mathrm{X} 4$ where X1 $=($ Current Assets - Current Liabilities $) /$ Total Assets; X2 = Retained Earnings/Total Assets; X3 = Earnings Before Interest and Taxes/Total Assets; X4 = Book Value of Equity/Total Liabilities.

27 Plant and machinery can also be mortgage collateral as long as they are inside the buildings.

280.82 in the case of non-distressed firms, 0.89 for distressed ones. All estimations are available upon request.

29 Since the number of employees were missing for a non-negligible part of the sample, values have been imputed using Poisson regressions for each country, where the predictor variables were a proprietary variable of Orbis that has four size categories according to several size measures (revenue, total assets, employees and whether the firm is listed) and industry dummies. The paper's results—available upon request—do not qualitatively change when total assets or turnover are used as alternative measures.
} 
may prefer to avoid the adverse publicity of a bankruptcy filing. To correct for right skewness we will take logs of age and size in our statistical analyses.

Table 3 shows the descriptive statistics of the variables for the non-distressed firms differentiating by country and size class (micro and non-micro). Spanish firms are smaller and younger than their French and UK counterparts in both groups. More remarkably, their mean levels of Tangibility are substantially higher than those of UK and France in the case of micro firms (Panel A), while only slightly higher in the case of larger firms (Panel B). We obtain similar results in the case of distressed firms (Table 4). Tangibility is also higher in Spain than in the other countries when we disaggregate by industry (Table 5). This evidence supports our hypothesis that Spanish firms have their capital structure biased towards mortgage collateral as a response to the particular insolvency framework they face, as in countries where the bankruptcy system is more effective vis-à-vis mortgage and the law grants less protection to mortgage creditors relative to other secured creditors (France, UK) firms have less tangible fixed assets relative to their financial debt.

\section{Empirical analyses}

Our hypothesis on the low business bankruptcy rates in Spain leads to two testable hypotheses regarding firms' behaviour ex-ante (i.e., prior default) and ex-post. From the ex-ante perspective, as filing for bankruptcy is very costly, small firms with risky business models will bias their capital structure towards mortgage loans to avoid filing for bankruptcy in the event of default. From the ex-post perspective, holding mortgage debt will reduce the probability of filing for bankruptcy by a small financially distressed firm. These two implications should not occur in the case of either Spanish larger businesses or firms from the other two countries.

\subsection{Ex-ante perspective: capital structure and business risk}

We run within-country regressions to assess the sign and size of the relationship between the proxy for the percentage of mortgage debt, Tangibility, and the ex-ante probability of default, as measured by the Altman's Z-score. ${ }^{30}$ We only use, from our sample, non-distressed firms, i.e., those whose interest coverage ratio is equal or greater than 1, which are not under bankruptcy procedures and are active in the market. We split the data into two sub-samples, one for micro firms and another one for non-micro firms.

Five different specifications, where Age, Size (both in logs), the limited liability dummy and 488 industry dummies ${ }^{31}$ are used as controls, are estimated through Tobit regressions. The results are displayed in Tables 6 (micro firms) and 7 (non-micro). The coefficient on the Z-score is negative for Spanish micro firms. As a lower Zscore represents a higher probability of default, the negative sign means that riskier

\footnotetext{
30 Although the Altman Z-Score was originally developed for bankruptcy prediction, it is now considered a good measure of other types of financial distress (Grice and Ingram 2001).

31 Industry is defined at 4 digits of disaggregation. NACE Rev. 1.1. classification.
} 
Table 3 Descriptive statistics (non-distressed firms)

\begin{tabular}{|c|c|c|c|c|c|}
\hline & Obs. & Mean & Std. dev. & Min & Max \\
\hline \multicolumn{6}{|l|}{ Panel A: micro firms } \\
\hline \multicolumn{6}{|l|}{ Spain } \\
\hline Tangibility & 143,491 & 148.2 & 148.0 & 0 & 797.0 \\
\hline Limited liability & 143,491 & 1.00 & 0.01 & 0 & 1 \\
\hline Age & 143,413 & 12.9 & 7.2 & 3 & 111 \\
\hline Size & 143,491 & 3.9 & 2.4 & 1 & 9 \\
\hline Z-Score & 143,491 & 2.1 & 3.1 & -12 & 16.5 \\
\hline \multicolumn{6}{|l|}{ France } \\
\hline Tangibility & 145,361 & 114.2 & 116.6 & 0 & 620.2 \\
\hline Limited liability & 145,361 & 1.00 & 0.06 & 0 & 1 \\
\hline Age & 145,342 & 12.1 & 9.7 & 3 & 177 \\
\hline Size & 145,361 & 3.3 & 2.3 & 1 & 9 \\
\hline Z-Score & 145,361 & 1.2 & 3.6 & -13 & 16.8 \\
\hline \multicolumn{6}{|l|}{ UK } \\
\hline Tangibility & 2,668 & 104.7 & 142.3 & 0 & 909.1 \\
\hline Limited liability & 2,668 & 1.00 & 0.03 & 0 & 1 \\
\hline Age & 2,668 & 16.6 & 14.8 & 3 & 149 \\
\hline Size & 2,668 & 4.3 & 2.5 & 1 & 9 \\
\hline Z-Score & 2,668 & 2.9 & 5.6 & -23 & 26.9 \\
\hline \multicolumn{6}{|c|}{ Panel D: non-micro firms } \\
\hline \multicolumn{6}{|l|}{ Spain } \\
\hline Tangibility & 64,750 & 157.0 & 149.8 & 0 & 797.0 \\
\hline Limited liability & 64,750 & 1.00 & 0.02 & 0 & 1 \\
\hline Age & 64,705 & 18.2 & 10.3 & 2 & 169 \\
\hline Size & 64,750 & 48.0 & 413.0 & 10 & 63.629 \\
\hline Z-Score & 64,750 & 2.5 & 2.5 & -12 & 16.3 \\
\hline \multicolumn{6}{|l|}{ France } \\
\hline Tangibility & 39,293 & 150.1 & 132.1 & 0 & 620.8 \\
\hline Limited liability & 39,293 & 0.99 & 0.09 & 0 & 1 \\
\hline Age & 39,293 & 23.5 & 16.4 & 3 & 211 \\
\hline Size & 39,293 & 61.5 & 499.6 & 10 & 72,199 \\
\hline Z-Score & 39,293 & 2.6 & 2.4 & -13 & 15.8 \\
\hline \multicolumn{6}{|l|}{ UK } \\
\hline Tangibility & 16,923 & 147.3 & 169.4 & 0 & 931.3 \\
\hline Limited liability & 16,923 & 1.00 & 0.05 & 0 & 1 \\
\hline Age & 16,923 & 26.3 & 20.4 & 3 & 155 \\
\hline Size & 16,923 & 348.8 & 2116.5 & 10 & 105,664 \\
\hline Z-Score & 16,923 & 2.6 & 3.0 & -22 & 21.6 \\
\hline
\end{tabular}

Tangibility is the ratio between tangible fixed assets to financial debt, in \%. Limited liability is a dummy that equals 1 if the firm is a limited-liability company and 0 otherwise. Age is number of years since registration. Size is the number of employees. Z-Score is the Altman's Z-Score for non-listed firms that do not necessarily belong to the manufacturing sector (Altman 2000) 
Table 4 Descriptive statistics (distressed firms)

\begin{tabular}{|c|c|c|c|c|c|}
\hline & Obs. & Mean & Std. dev. & Min & Max \\
\hline \multicolumn{6}{|l|}{ Panel A: micro firms } \\
\hline \multicolumn{6}{|l|}{ Spain } \\
\hline Bankruptcy & 31,009 & 0.03 & 0.2 & 0 & 1 \\
\hline Tangibility & 31,009 & 94.3 & 101.1 & 0 & 540.2 \\
\hline Limited liability & 31,009 & 1.00 & 0.01 & 0 & 1 \\
\hline Age & 30,987 & 12.2 & 7.7 & 3 & 111 \\
\hline Size & 31,009 & 3.5 & 2.3 & 1 & 9 \\
\hline Z-Score & 31,009 & -1.4 & 5.5 & -22.4 & 20.0 \\
\hline \multicolumn{6}{|l|}{ France } \\
\hline Bankruptcy & 34,677 & 0.13 & 0.3 & 0 & 1 \\
\hline Tangibility & 34,677 & 66.3 & 74.1 & 0 & 394.7 \\
\hline Limited liability & 34,677 & 1.00 & 0.07 & 0 & 1 \\
\hline Age & 34,676 & 12.6 & 10.9 & 2 & 197 \\
\hline Size & 34,677 & 3.9 & 2.2 & 1 & 9 \\
\hline Z-Score & 34,677 & -2.5 & 5.1 & -22.0 & 17.9 \\
\hline \multicolumn{6}{|l|}{ UK } \\
\hline Bankruptcy & 1,710 & 0.12 & 0.3 & 0 & 1 \\
\hline Tangibility & 1,710 & 70.8 & 89.8 & 0 & 504.4 \\
\hline Limited liability & 1,710 & 1.00 & 0.02 & 0 & 1 \\
\hline Age & 1,710 & 14.4 & 13.0 & 3 & 106 \\
\hline Size & 1,710 & 6.1 & 2.4 & 1 & 9 \\
\hline Z-Score & 1,710 & -3.3 & 7.6 & -33.9 & 19.0 \\
\hline \multicolumn{6}{|c|}{ Panel B: non-micro firms } \\
\hline \multicolumn{6}{|l|}{ Spain } \\
\hline Bankruptcy & 8,583 & 0.14 & 0.3 & 0 & 1 \\
\hline Tangibility & 8,583 & 94.7 & 101.5 & 0 & 540.0 \\
\hline Limited liability & 8,583 & 1.00 & 0.03 & 0 & 1 \\
\hline Age & 8,577 & 17.2 & 11.2 & 3 & 169 \\
\hline Size & 8,583 & 38.7 & 110.6 & 10 & 3,538 \\
\hline Z-Score & 8,583 & -0.9 & 4.6 & -22.4 & 17.8 \\
\hline \multicolumn{6}{|l|}{ France } \\
\hline Bankruptcy & 12,783 & 0.22 & 0.4 & 0 & 1 \\
\hline Tangibility & 12,783 & 80.8 & 65.7 & 0 & 394.1 \\
\hline Limited liability & 12,783 & 0.98 & 0.14 & 0 & 1 \\
\hline Age & 12,783 & 19.4 & 16.0 & 3 & 208 \\
\hline Size & 12,783 & 40.1 & 181.4 & 10 & 15.521 \\
\hline Z-Score & 12,783 & -1.2 & 4.5 & -22.0 & 18.1 \\
\hline \multicolumn{6}{|l|}{ UK } \\
\hline Bankruptcy & 7,051 & 0.15 & 0.4 & 0 & 1 \\
\hline Tangibility & 7,051 & 78.6 & 91.6 & 0 & 518.5 \\
\hline
\end{tabular}


Table 4 continued

\begin{tabular}{lccccc}
\hline & Obs. & Mean & Std. dev. & Min & Max \\
\hline Limited liability & 7,051 & 1.00 & 0.06 & 0 & 1 \\
Age & 7,051 & 19.5 & 19.2 & 3 & 141 \\
Size & 7,051 & 192.6 & 1022.8 & 10 & 40,855 \\
Z-Score & 7,051 & -2.3 & 6.5 & -34.1 & 13.9 \\
\hline
\end{tabular}

Bankruptcy is a dummy that equals 1 if the firm is bankrupt and 0 otherwise. Tangibility is the ratio between tangible fixed assets to financial debt, in \%. Limited liability is a dummy that equals 1 if the firm is a limited-liability company and 0 otherwise. Age is number of years since registration. Size is the number of employees. Z-Score is the Altman's Z-Score for non-listed firms that do not necessarily belong to the manufacturing sector (Altman 2000)

firms rely more on mortgage collateral, suggesting that those firms bias their capital structure towards mortgage loans to avoid filing for bankruptcy if they experienced financial distress. The impact is also economically significant: a unit-decrease in the Z-score would increase Tangibility between two or three percentage points, depending on the specification. By contrast, the coefficient on the Z-score is positive in the rest of cases: firms with risky business models usually have little collateral to pledge, as their main assets are know-how, intellectual property -often unregistered- and firm-specific human capital and machinery. ${ }^{32}$

\subsection{Ex-post perspective: capital structure and bankruptcy risk}

A first descriptive check can be found in Table 8, where we split our sub-sample of distressed firms into bankrupt and non-bankrupt for each size class and each country. In the case of micro firms (panel A), distressed non-bankrupt firms have much higher levels of Tangibility in Spain, while the opposite occurs in France and the UK. Nonmicro firms follow the same pattern, but the positive gap between bankrupt and nonbankrupt in Spain is now smaller. As expected, non-bankrupt Spanish firms are smaller and younger for both size classes, while those patterns are not so clear in France and the UK.

A more thorough test consists of running within-country regressions to assess the sign and size of the relationship between the proxy for the percentage of mortgage debt, Tangibility, and the probability of filing for bankruptcy by a financially distressed firm in each country, once other determinants are controlled for. We split the data into two sub-samples, one for micro firms and another one for non-micro firms. In analytical terms what we estimate is the following model:

$$
\begin{aligned}
& \left.P \text { (Bankruptcy }_{i} / \text { FinancialDistress }\right) \\
& \quad=f\left(\text { Tangibility }_{i}, \text { Control }_{i}, \ldots, \text { ControlK }_{i}, u_{i}\right)
\end{aligned}
$$

\footnotetext{
32 An alternative explanation could be that firms with worse financials (lower Z-score) may not heavily invest in long-term costly assets such as land and buildings relative to their debt levels because they suffer from credit rationing. But, if that were the main reason, it would be very difficult to make sense of the case of Spanish micro firms, where the opposite would occur.
} 
Table 5 Descriptive statistics of tangibility by industry (distressed and non-distressed firms)

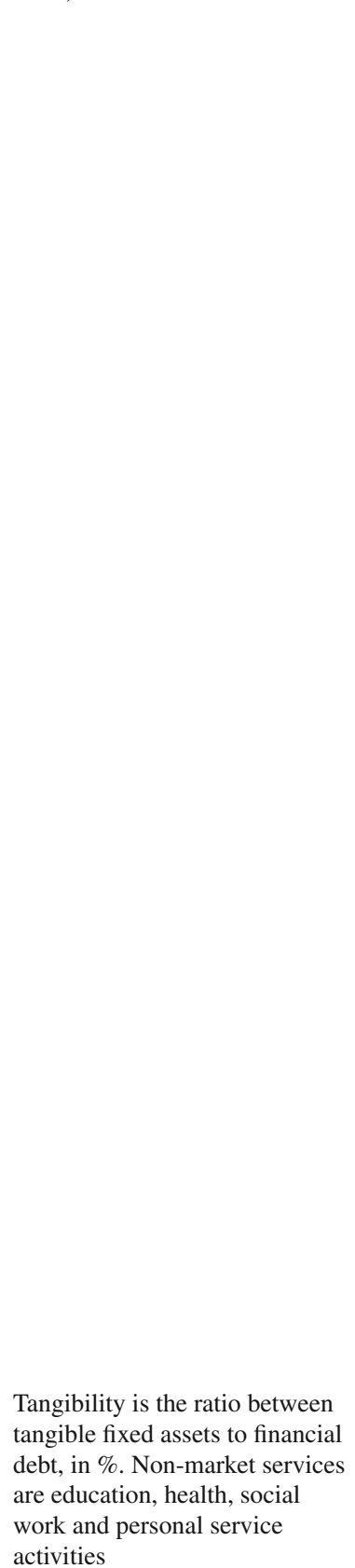

\begin{tabular}{lll}
\hline Spain & France & UK \\
\hline
\end{tabular}

Panel A: distressed firms

Primary sector
Mean

$\begin{array}{llll}\text { Mean } & 129.6 & 106.7 & 114.5 \\ \text { St. Dev. } & (113.2) & (86.5) & (120.7) \\ \text { N } & 1,151 & 717 & 180\end{array}$

Manufacturing and energy

$\begin{array}{llll}\text { Mean } & 109.6 & 85.0 & 70.2 \\ \text { St. Dev. } & (102.0) & (85.4) & (84.1) \\ \text { N } & 5,083 & 5,299 & 1,110\end{array}$

Construction

$\begin{array}{llll}\text { Mean } & 90.9 & 76.4 & 78.7\end{array}$

St. Dev. (100.8) (74.6)

$\begin{array}{llll}\mathrm{N} & 5,604 & 4,684 & 660\end{array}$

Market services

$\begin{array}{llll}\text { Mean } & 88.9 & 65.5 & 75.7 \\ \text { St. Dev. } & (99.7) & (76.0) & (89.4) \\ \text { N } & 25,854 & 33,415 & 5.927\end{array}$

Non-market services

$\begin{array}{llll}\text { Mean } & 117.2 & 77.0 & 86.2 \\ \text { St. Dev. } & (100.8) & (77.4) & (97.7) \\ \text { N } & 1,900 & 3,345 & 884\end{array}$

Panel B: non-distressed firms

Primary sector

$\begin{array}{llll}\text { Mean } & 179.4 & 156.4 & 171.7 \\ \text { St. Dev. } & (156.5) & (112.7) & (190.3) \\ \text { N } & 5,998 & 4,416 & 385\end{array}$

Manufacturing and energy

$\begin{array}{llll}\text { Mean } & 163.2 & 140.5 & 160.2 \\ \text { St. Dev. } & (149.2) & (126.8) & (175.1) \\ \text { N } & 35,928 & 23,208 & 4,636\end{array}$

Construction

$\begin{array}{llll}\text { Mean } & 137.5 & 143.9 & 153.8 \\ \text { St. Dev. } & (141.3) & (117.49) & (174.3) \\ \text { N } & 34,723 & 31,173 & 1,821\end{array}$

Market services

\begin{tabular}{llll} 
Mean & 147.0 & 111.5 & 127.7 \\
St. Dev. & $(148.8)$ & $(120.0)$ & $(158.0)$ \\
N & 118,979 & 110,894 & 11,020 \\
Non-market services & & & \\
Mean & 175.8 & 113.2 & 159.1 \\
St. Dev. & $(154.0)$ & $(118.6)$ & $(175.3)$ \\
N & 12,613 & 14,963 & 1,729 \\
\hline
\end{tabular}


Table 6 Determinants of tangibility (micro firms)

\begin{tabular}{|c|c|c|c|c|c|}
\hline & (1) & (2) & (3) & (4) & $(5)$ \\
\hline \multicolumn{6}{|l|}{ Spain } \\
\hline Z-Score & $\begin{array}{c}-1.89 * * * \\
(0.15)\end{array}$ & $\begin{array}{c}-2.77 * * * \\
(0.16)\end{array}$ & $\begin{array}{c}-2.78 * * * \\
(0.16)\end{array}$ & $\begin{array}{c}-1.93 * * * \\
(0.16)\end{array}$ & $\begin{array}{c}-1.93^{* * * *} \\
(0.16)\end{array}$ \\
\hline Log (age) & & $\begin{array}{c}31.92 * * * \\
(0.72)\end{array}$ & $\begin{array}{c}30.04 * * * \\
(0.73)\end{array}$ & $\begin{array}{c}28.51 * * * * \\
(0.74)\end{array}$ & $\begin{array}{c}28.49 * * * \\
(0.74)\end{array}$ \\
\hline $\log ($ size $)$ & & & $\begin{array}{c}10.86^{* * * *} \\
(0.57)\end{array}$ & $\begin{array}{r}9.34 * * * * \\
(0.59)\end{array}$ & $\begin{array}{r}9.34 * * * \\
(0.59)\end{array}$ \\
\hline Limited liability & & & & & $\begin{array}{r}-60.01 \\
\quad(61.27)\end{array}$ \\
\hline Industry dummies (4 digits) & No & No & No & Yes & Yes \\
\hline $\mathrm{N}$ & 143,491 & 143,413 & 143,413 & 143,413 & 143,413 \\
\hline Pseudo-R2 (\%) & 0.01 & 0.12 & 0.14 & 0.38 & 0.38 \\
\hline \multicolumn{6}{|l|}{ France } \\
\hline Z-Score & $\begin{array}{r}5.11 * * * \\
(0.09)\end{array}$ & $\begin{array}{r}3.67 * * * \\
(0.09)\end{array}$ & $\begin{array}{r}3.64 * * * \\
(0.09)\end{array}$ & $\begin{array}{r}3.63 * * * \\
(0.10)\end{array}$ & $\begin{array}{r}3.63 * * * \\
(0.10)\end{array}$ \\
\hline Log (age) & & $\begin{array}{c}32.01 * * * \\
(0.49)\end{array}$ & $\begin{array}{c}30.70 * * * \\
(0.51)\end{array}$ & $\begin{array}{c}31.22 * * * \\
(0.51)\end{array}$ & $\begin{array}{c}31.25 * * * \\
(0.51)\end{array}$ \\
\hline $\log ($ size $)$ & & & $\begin{array}{r}4.84 * * * \\
(0.43)\end{array}$ & $\begin{array}{r}4.17 * * * \\
(0.44)\end{array}$ & $\begin{array}{r}4.16^{* * * *} \\
(0.44)\end{array}$ \\
\hline Limited liability & & & & & $\begin{array}{c}20.27 * * * \\
(4.71)\end{array}$ \\
\hline Industry dummies (4 digits) & No & No & No & Yes & Yes \\
\hline $\mathrm{N}$ & 145,361 & 145,342 & 145,342 & 145,342 & 145,342 \\
\hline Pseudo-R2 (\%) & 0.22 & 0.47 & 0.48 & 0.94 & 0.94 \\
\hline \multicolumn{6}{|l|}{ UK } \\
\hline Z-Score & $\begin{array}{r}2.98 * * * \\
(0.40)\end{array}$ & $\begin{array}{r}2.95 * * * \\
(0.40)\end{array}$ & $\begin{array}{r}2.95 * * * \\
(0.40)\end{array}$ & $\begin{array}{r}3.84 * * * \\
(0.43)\end{array}$ & $\begin{array}{r}3.83 * * * \\
(0.43)\end{array}$ \\
\hline Log (age) & & $\begin{array}{c}33.86^{* * *} * \\
(3.96)\end{array}$ & $\begin{array}{c}33.83 * * * \\
(4.04)\end{array}$ & $\begin{array}{c}30.25 * * * \\
(4.28)\end{array}$ & $\begin{array}{c}30.24 * * * \\
(4.28)\end{array}$ \\
\hline $\log ($ size $)$ & & & $0.17(4.18)$ & $\begin{array}{r}7.87 * \\
(4.19)\end{array}$ & $\begin{array}{r}7.85^{*} \\
\quad(4.19)\end{array}$ \\
\hline Limited liability & & & & & $\begin{array}{l}22.68 \\
\quad(30.46)\end{array}$ \\
\hline Industry dummies (4 digits) & No & No & No & Yes & Yes \\
\hline $\mathrm{N}$ & 2,668 & 2,668 & 2,668 & 2,668 & 2,668 \\
\hline Pseudo-R2 (\%) & 0.10 & 0.34 & 0.34 & 1.62 & 1.62 \\
\hline
\end{tabular}

Dependent variable: tangibility. Estimator: Tobit. Industry is defined at 4 digits of disaggregation, leading to 488 different dummies. All regressions include a constant. Robust standard errors in parentheses. *, **, and $* * *$, significant at 10,5 , and $1 \%$ level

Notice that we do not face a sample selection bias by only keeping the financially distressed firms. Denoting $S_{i}$ as a selection indicator that equals 1 if the observation is included in the sample and 0 otherwise, and icr the interest coverage ratio: $S_{i}=1$ if $i c r_{i}<1 ; S_{i}=0$ if $i c r_{i} \geq 1$. As long as icr is uncorrelated with $u$, the unobserved 
Table 7 Determinants of tangibility (non-micro firms)

\begin{tabular}{|c|c|c|c|c|c|}
\hline & (1) & (2) & (3) & (4) & (5) \\
\hline \multicolumn{6}{|l|}{ Spain } \\
\hline Z-Score & $\begin{array}{r}6.88 * * * \\
(0.29)\end{array}$ & $\begin{array}{c}6.16^{* * * *} \\
(0.29)\end{array}$ & $\begin{array}{r}6.03 * * * \\
(0.29)\end{array}$ & $\begin{array}{r}8.28 * * * \\
(0.29)\end{array}$ & $\begin{array}{r}8.28 * * * \\
(0.29)\end{array}$ \\
\hline Log (age) & & $\begin{array}{c}15.89 * * * \\
(1.05)\end{array}$ & $\begin{array}{c}19.75 * * * \\
(1.08)\end{array}$ & $\begin{array}{c}17.95 * * * \\
(1.12)\end{array}$ & $\begin{array}{c}17.94 * * * \\
(1.12)\end{array}$ \\
\hline $\log ($ size $)$ & & & $\begin{array}{c}-11.44 * * * \\
(0.77)\end{array}$ & $\begin{array}{c}-11.80 * * * \\
(0.78)\end{array}$ & $\begin{array}{l}-11.81 * * * \\
(0.78)\end{array}$ \\
\hline Limited liability & & & & & $\begin{array}{r}-48.66 \\
(47.28)\end{array}$ \\
\hline Industry dummies (4 digits) & No & No & No & Yes & Yes \\
\hline $\mathrm{N}$ & 64,750 & 64,705 & 64,532 & 64,532 & 64,532 \\
\hline Pseudo-R2 (\%) & 0.10 & 0.13 & 0.15 & 0.54 & 0.54 \\
\hline \multicolumn{6}{|l|}{ France } \\
\hline Z-Score & $\begin{array}{r}8.66^{* * * *} \\
(0.28)\end{array}$ & $\begin{array}{r}7.17 * * * \\
(0.29)\end{array}$ & $\begin{array}{r}7.27 * * * \\
(0.29)\end{array}$ & $\begin{array}{c}9.15^{* * * *} \\
(0.31)\end{array}$ & $\begin{array}{r}9.15^{* * * *} \\
(0.31)\end{array}$ \\
\hline Log (age) & & $\begin{array}{c}25.10 * * * \\
(0.99)\end{array}$ & $\begin{array}{c}23.17 * * * \\
(1.03)\end{array}$ & $\begin{array}{c}22.84 * * * \\
(1.05)\end{array}$ & $\begin{array}{c}22.85 * * * \\
(1.05)\end{array}$ \\
\hline Log (Size) & & & $\begin{array}{c}6.29 * * * \\
(0.87)\end{array}$ & $\begin{array}{c}5.33 * * * \\
(0.89)\end{array}$ & $\begin{array}{r}5.32 * * * \\
(0.89)\end{array}$ \\
\hline Limited liability & & & & & $\begin{array}{r}-2.05 \\
(8.35)\end{array}$ \\
\hline Industry dummies (4 digits) & No & No & No & Yes & Yes \\
\hline $\mathrm{N}$ & 39,293 & 39,293 & 38,818 & 38,818 & 38,818 \\
\hline Pttudo-R2 (\%) & 0.21 & 0.33 & 0.35 & 1.03 & 1.03 \\
\hline \multicolumn{6}{|l|}{ UK } \\
\hline Z-Score & $\begin{array}{c}9.72 * * * \\
(0.45)\end{array}$ & $\begin{array}{c}8.59 * * * \\
(0.44)\end{array}$ & $\begin{array}{c}8.67 * * * \\
(0.45)\end{array}$ & $\begin{array}{c}11.04 * * * \\
(0.48)\end{array}$ & $\begin{array}{c}11.04 * * * \\
(0.48)\end{array}$ \\
\hline $\log ($ age $)$ & & $\begin{array}{c}31.29 * * * \\
(1.70)\end{array}$ & $\begin{array}{c}30.92 * * * \\
(1.71)\end{array}$ & $\begin{array}{c}27.12 * * * \\
(1.81)\end{array}$ & $\begin{array}{c}27.16^{* * * *} \\
(1.81)\end{array}$ \\
\hline $\log ($ size $)$ & & & $\begin{array}{l}1.80^{*} \\
(0.98)\end{array}$ & $\begin{array}{l}0.22 \\
\quad(1.01)\end{array}$ & $\begin{array}{l}0.27 \\
\quad(1.01)\end{array}$ \\
\hline Limited liability & & & & & $\begin{array}{l}27.21 \\
\quad(30.97)\end{array}$ \\
\hline Industry dummies (4 digits) & No & No & No & Yes & Yes \\
\hline $\mathrm{N}$ & 16,923 & 16,923 & 16,923 & 16,923 & 16,923 \\
\hline Pseudo-R2 (\%) & 0.23 & 0.37 & 0.37 & 1.02 & 1.02 \\
\hline
\end{tabular}

Dependent variable: tangibility. Estimator: Tobit. Industry is defined at 4 digits of disaggregation, leading to 488 different dummies. All regressions include a constant. Robust standard errors in parentheses. *, **, and $* * *$, significant at 10,5 , and $1 \%$ level

that factors that influence the decision to file for bankruptcy conditional on being in financial distress, our sampling mechanism $S($ icr $)$ will be exogenous. As our dependent variable, BANKRUPTCY, is measured in 2010, while the interest coverage ratio icr is measured in 2008, it seems safe to assume that BANKRUPTCY cannot have any influence on $i c r$, implying $E\left[u_{i} / S\left(i c r_{i}\right)\right]=0$. 


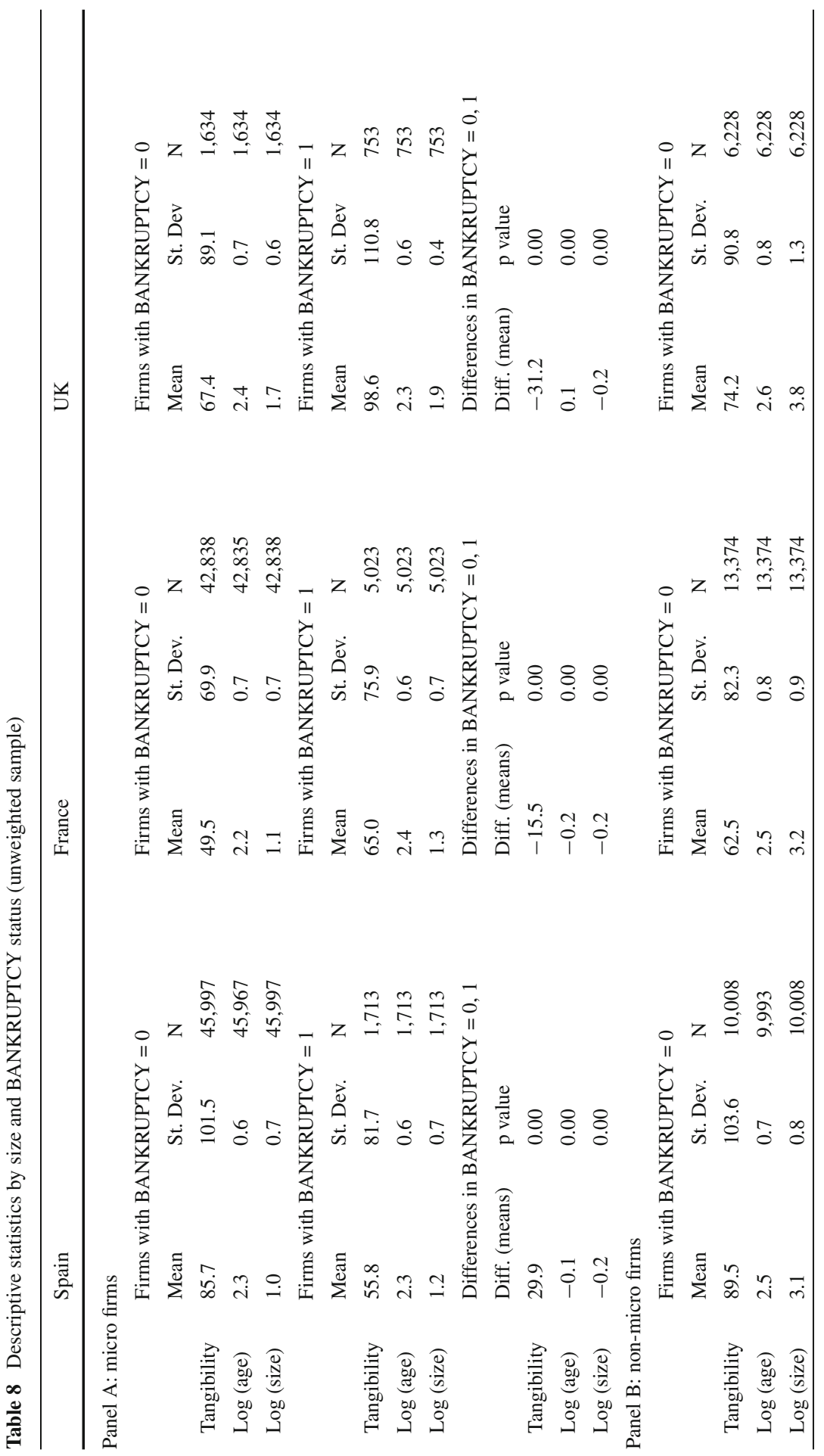




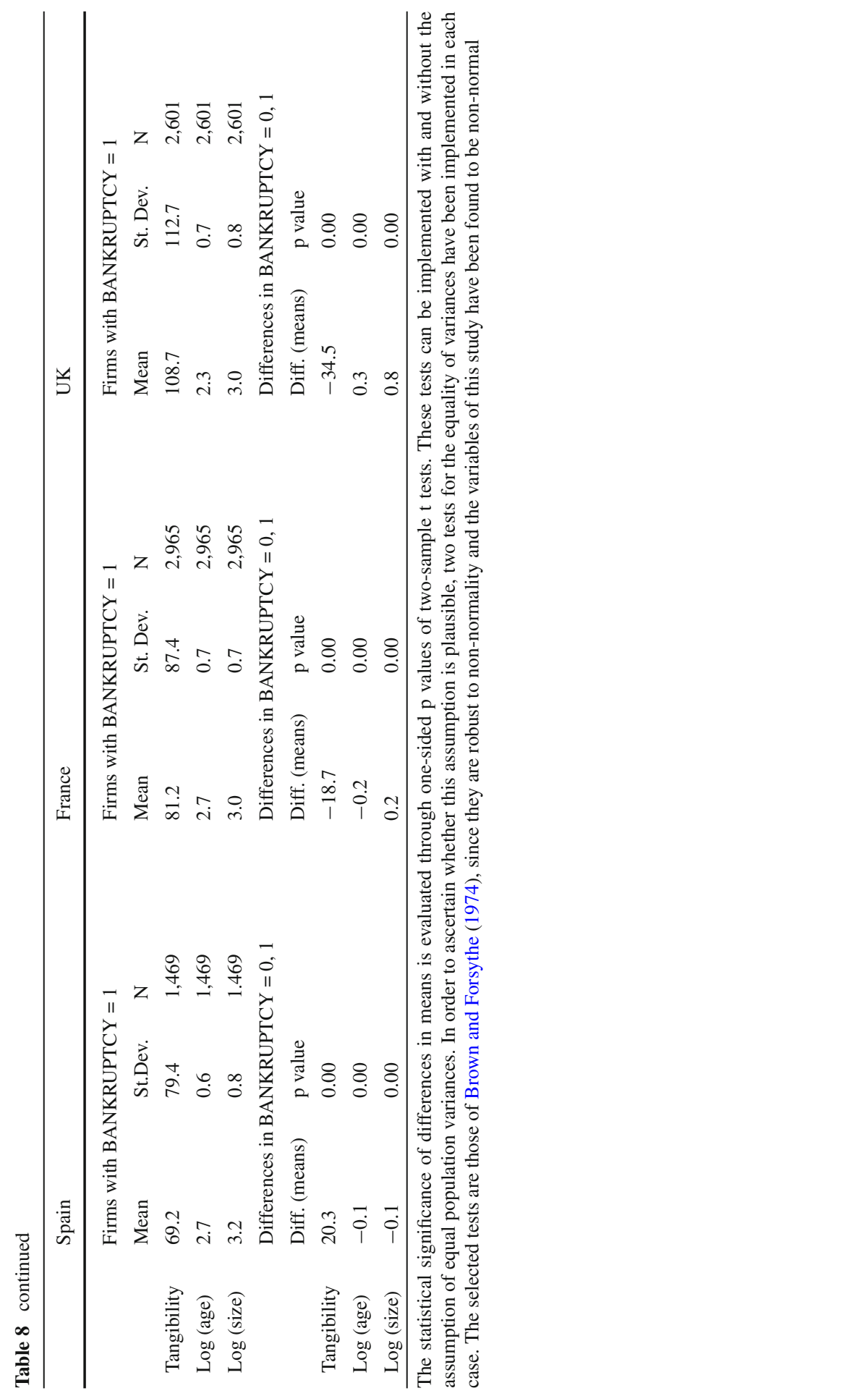


In the case of micro firms, the first set of results is shown in Table 9, which displays OLS regressions ${ }^{33}$ for the probability of bankruptcy. Five specifications, where Age, Size (both in logs), the limited liability dummy and 14 dummies for industry ${ }^{34}$ are used as controls, are shown for robustness. The table reveals that Tangibility is negatively correlated with the probability of bankruptcy in Spain, while positivelycorrelated in France and the UK.

However, we expect the estimates of Table 9 to be biased due to the endogeneity of capital structure, as explained in the previous section. In other words, as firms' capital structure and the mechanism used to deal with insolvency are (ex-ante) jointly chosen by firms, we face a simultaneity bias. Moreover, we expect Tangibility to be measured with error because tangible fixed assets are valued at their acquisition (historical) cost, which may differ from their market/collateral values. To solve these problems we use as instrumental variable (IV) the average industry level of Tangibility-where industry is defined at 4 digits of disaggregation, leading to 473 different classes - for each size class (micro and non-micro). ${ }^{35}$ We expect this IV to be uncorrelated with any unobserved determinant of the probability of bankruptcy of a single firm because no firm chooses the asset and capital structure of its industry counterparts. Moreover, there is a positive and sizeable correlation between the IV and the endogenous regressor-as reflected by first-stage regressions ${ }^{36}$ - since companies for the same industries tend to have similar levels of tangibility.

The selected IV estimator is two-stage least squares (2SLS). We prefer not to use IV probit as our main estimator because its consistency relies in some strong assumptions such as conditional normality of the endogenous regressor (Wooldridge 2002) that do not seem to hold in our case. Despite the well-known caveats of the linear probability model (heteroskedasticity, fitted probabilities out of $[0,1]$ ), it requires weaker assumptions and it usually provides good approximations of the marginal effects (Angrist and Pischke 2009). ${ }^{37}$

The results for the estimation via 2SLS are displayed in Table 10. In the regressions for the Spanish subsample, the marginal effects of Tangibility are negative and highly significant, and they are substantially higher than those estimated without instrumenting the regressor. They are also economically significant. A $1 \%$ increase in Tangibility - a small change, as its mean equals $85 \%$ and its standard deviation $101 \%$ - decreases the probability of filing for bankruptcy by a Spanish micro firm by

\footnotetext{
33 We use the linear probability model to avoid the separation problem we would face with non-linear models such as logit or probit, as no Spanish firm with unlimited liability is bankrupt in our sample, i.e, we have an empty cell for (Limited liability $=0$, Bankruptcy $=1$ ).

34 NACE Rev. 1.1. at the maximum aggregation level, e.g. D. Manufacturing.

35 The average level of tangibility is computed for each industry, regardless of the country. Although we could have instead computed the average industry-country level of tangibility to increase the variability of the IV, that variable may not be exogenous, since it may be influenced by the country's institutional framework.

36 Results available upon request.

37 Nevertheless, similar conclusions are reached when IV probit is used instead. Results available upon request.
} 


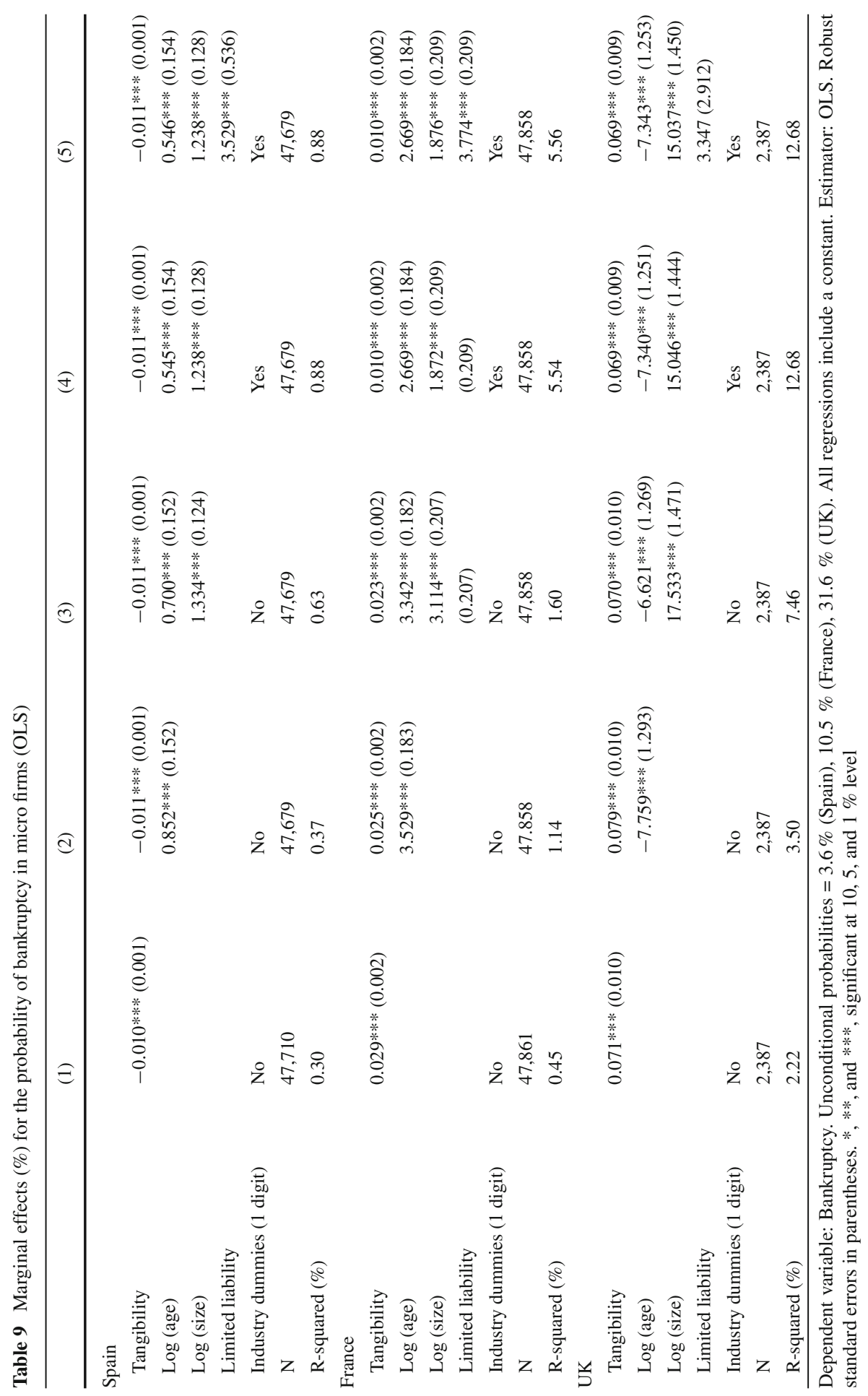


Table 10 Marginal effects (\%) for the probability of bankruptcy in micro firms (2SLS)

\begin{tabular}{|c|c|c|c|c|c|}
\hline & (1) & (2) & (3) & (4) & (5) \\
\hline \multicolumn{6}{|l|}{ Spain } \\
\hline Tangibility & $\begin{array}{c}-0.012 * * * \\
(0.003)\end{array}$ & $\begin{array}{c}-0.014 * * * \\
(0.003)\end{array}$ & $\begin{array}{c}-0.017 * * * \\
(0.003)\end{array}$ & $\begin{array}{c}-0.027 * * * \\
(0.004)\end{array}$ & $\begin{array}{c}-0.027 * * * \\
(0.004)\end{array}$ \\
\hline Log (age) & & $\begin{array}{r}0.909 * * * \\
(0.160)\end{array}$ & $\begin{array}{r}0.809 * * * \\
(0.159)\end{array}$ & $\begin{array}{r}0.807 * * * \\
(0.170)\end{array}$ & $\begin{array}{r}0.807 * * * \\
(0.170)\end{array}$ \\
\hline $\log ($ size $)$ & & & $\begin{array}{r}1.362 * * * \\
(0.124)\end{array}$ & $\begin{array}{r}1.227 * * * \\
(0.128)\end{array}$ & $\begin{array}{r}1.227 * * * \\
(0.128)\end{array}$ \\
\hline Limited liability & & & & & $\begin{array}{r}3.609 * * * \\
(0.850)\end{array}$ \\
\hline Industry dummies (1 digit) & No & No & No & Yes & Yes \\
\hline $\mathrm{N}$ & 47,710 & 47,679 & 47,679 & 47,679 & 47,679 \\
\hline \multicolumn{6}{|l|}{ France } \\
\hline Tangibility & $\begin{array}{r}0.181 * * * \\
(0.005)\end{array}$ & $\begin{array}{r}0.176^{* * * *} \\
(0.006)\end{array}$ & $\begin{array}{r}0.168 * * * \\
(0.006)\end{array}$ & $\begin{array}{r}0.071 * * * \\
(0.007)\end{array}$ & $\begin{array}{r}0.072 * * * \\
(0.007)\end{array}$ \\
\hline Log (age) & & $\begin{array}{r}1.867 * * * \\
(0.205)\end{array}$ & $\begin{array}{r}1.816^{* * * *} \\
(0.203)\end{array}$ & $\begin{array}{r}2.070 * * * \\
(0.196)\end{array}$ & $\begin{array}{r}2.064 * * * \\
(0.196)\end{array}$ \\
\hline $\log ($ size $)$ & & & $\begin{array}{r}1.960 * * * \\
(0.221)\end{array}$ & $\begin{array}{r}1.644 * * * \\
(0.212)\end{array}$ & $\begin{array}{r}1.646^{* * * *} \\
(0.212)\end{array}$ \\
\hline Limited liability & & & & & $\begin{array}{r}3.707 * * * \\
(0.797)\end{array}$ \\
\hline Industry dummies (1 digit) & No & No & No & Yes & Yes \\
\hline $\mathrm{N}$ & 47,861 & 47,858 & 47,858 & 47,858 & 47,858 \\
\hline \multicolumn{6}{|l|}{ UK } \\
\hline Tangibility & $\begin{array}{r}0.233 * * * \\
(0.068)\end{array}$ & $\begin{array}{r}0.222 * * * \\
(0.064)\end{array}$ & $\begin{array}{l}0.142 * * \\
\quad(0.064)\end{array}$ & $\begin{array}{l}0.132 * \\
\quad(0.074)\end{array}$ & $\begin{array}{l}0.132 * \\
\quad(0.074)\end{array}$ \\
\hline Log (age) & & $\begin{array}{c}-10.777 * * * \\
(1.897)\end{array}$ & $\begin{array}{c}-8.184 * * * \\
(1.866)\end{array}$ & $\begin{array}{c}-8.640 * * * \\
(1.954)\end{array}$ & $\begin{array}{c}-8.641 * * * \\
(1.953)\end{array}$ \\
\hline $\log ($ size $)$ & & & $\begin{array}{c}16.376 * * * \\
(1.753)\end{array}$ & $\begin{array}{c}14.020 * * * \\
(1.838)\end{array}$ & $\begin{array}{c}14.016 * * * \\
(1.839)\end{array}$ \\
\hline Limited liability & & & & & $\begin{array}{l}1.389 \\
(3.827)\end{array}$ \\
\hline Industry dummies (1 digit) & No & No & No & Yes & Yes \\
\hline $\mathrm{N}$ & 2,387 & 2,387 & 2,387 & 2,387 & 2,387 \\
\hline
\end{tabular}

Dependent variable: Bankruptcy. Unconditional probabilities $=3.6 \%$ (Spain), $10.5 \%$ (France), $31.6 \%$ (UK). All regressions include a constant. Estimator: 2SLS. Robust standard errors in parentheses. *, **, and $* * *$, significant at 10,5 , and $1 \%$ level

around $0.03 \% .^{38}$ As the unconditional probability ${ }^{39}$ of those firms is $3.6 \%$, the estimated semielasticity is $0.83 \%$, which is a sizeable effect. By contrast, the marginal

\footnotetext{
38 One could argue that Tangibility is really a proxy for leverage and what we are capturing is a lower probability of using bankruptcy for firms with lower leverage. To rule out that alternative explanation, we have computed a leverage ratio, defined as financial debt over total assets. The correlation between the leverage ratio and Tangibility is very low, especially in the case of Spanish micro firms: -0.07 .

39 By unconditional probability we mean the sample proportion of bankrupt firms.
} 
effects of Tangibility are positive and significant both in France and the UK. This latter result is consistent with the results of Davydenko and Franks (2008) on their study of French, UK and German firms that defaulted on their bank debt. They find that higher levels of collateral imply a significantly higher incidence of bankruptcies and a somewhat higher probability of liquidation, suggesting that banks use formal bankruptcy procedures to force a sale of collateral in those countries. This is not the Spanish case, as there is an alternative insolvency procedure, a mortgage foreclosure, through which collateral can be more efficiently liquidated.

With respect to the control variables, size has a positive impact in the probability of bankruptcy in the three countries, suggesting that the fixed costs of bankruptcy procedures deter very small firms from using them, as argued by Morrison (2008). Age has a negative effect in the case of UK, suggesting that lower information asymmetries and higher reputation concerns incentivise older firms to avoid bankruptcy. By contrast, it has a positive impact in the Spanish and French subsamples, probably capturing the fact that, as older firms have more lenders, higher coordination costs reduce the chances of non-bankruptcy procedures. Limited liability has a positive effect in three countries - although not significant at $10 \%$ in the $\mathrm{UK}^{40}$ — consistent with the idea that, when the debtor may lose part of its personal wealth, she has fewer incentives to file for bankruptcy, even when some partial discharge — as in France and in the UK-may be granted.

The case of non-micro firms is analysed in Tables 11 and 12. As a benchmark, Table 11 shows the (biased) OLS estimates for the three countries, which reveals the same patterns as for micro firms: negative correlations in Spain and positive correlations in France and the UK.

By contrast, the consistent IV estimates in Table 12 show that Tangibility has a positive impact on the probability of bankruptcy of Spanish non-micro firms in 3 out of the 4 specifications and it is not significant in specification (4), suggesting that it is not a robust determinant. The case of French and UK larger firms is similar to the one for micro: Tangibility has a robust positive impact in the probability of bankruptcy.

With respect to the control variables, size has a positive impact in the probability of bankruptcy in Spain — as it was the case in the subsample of micro firms — but a negative one in France and the UK. A possible interpretation is that the fixed costs of bankruptcy proceedings deter small and very small firms from using them but, in the case of quite large firms, other factors, such as the reputational loss of managers, make filing for bankruptcy less appealing. As in the case of micro firms, age has a positive effect in the Spanish subsample, but a negative one in the UK and no robust impact in France.

5.3 Robustness analysis of the ex-post perspective: private workouts and subsample of firm exits

In our sample of distressed firms we have two types: bankrupt and non-bankrupt. The former consists of firms under bankruptcy proceedings (i.e., still operating in the

\footnotetext{
40 Notice the large standard errors of the variable in the UK (Tables 8, 9), consequence of its little variability: only $0.03 \%$ of the micro UK firms in the sample had (un)limited liability.
} 
Table 11 Marginal effects (\%) for the probability of bankruptcy in non-micro firms (OLS)

\begin{tabular}{|c|c|c|c|c|c|}
\hline & (1) & (2) & (3) & (4) & (5) \\
\hline \multicolumn{6}{|l|}{ Spain } \\
\hline Tangibility & $\begin{array}{c}-0.022^{* * * *} \\
(0.003)\end{array}$ & $\begin{array}{c}-0.025 * * * \\
(0.003)\end{array}$ & $\begin{array}{c}-0.024 * * * \\
(0.003)\end{array}$ & $\begin{array}{c}-0.026 * * * \\
(0.003)\end{array}$ & $\begin{array}{c}-0.026^{* * * *} \\
(0.003)\end{array}$ \\
\hline Log (age) & & $\begin{array}{r}3.735 * * * \\
(0.462)\end{array}$ & $\begin{array}{r}3.446 * * * \\
(0.464)\end{array}$ & $\begin{array}{r}1.550 * * * \\
(0.487)\end{array}$ & $\begin{array}{r}1.561 * * * \\
(0.487)\end{array}$ \\
\hline $\log ($ size $)$ & & & $\begin{array}{r}2.063 * * * \\
(0.394)\end{array}$ & $\begin{array}{r}2.521 * * * \\
(0.400)\end{array}$ & $\begin{array}{r}2.545 * * * \\
(0.400)\end{array}$ \\
\hline Limited liability & & & & & $\begin{array}{c}15.141 * * * \\
(3.053)\end{array}$ \\
\hline Industry dummies (1 digit) & No & No & No & Yes & Yes \\
\hline $\mathrm{N}$ & 11,477 & 11,462 & 11,462 & 11,462 & 11,462 \\
\hline $\mathrm{R}$-squared (\%) & 0.45 & 0.98 & 1.21 & 4.53 & 4.55 \\
\hline \multicolumn{6}{|l|}{ France } \\
\hline Tangibility & $(0.040)^{* * *}$ & $\begin{array}{r}0.035 * * * \\
(0.004)\end{array}$ & $\begin{array}{r}0.034 * * * \\
(0.004)\end{array}$ & $\begin{array}{l}0.008 * * \\
(0.004)\end{array}$ & $\begin{array}{l}0.008 * * \\
(0.004)\end{array}$ \\
\hline Log (age) & & $\begin{array}{r}3.418 * * * \\
(0.353)\end{array}$ & $\begin{array}{r}4.081 * * * \\
(0.355)\end{array}$ & $\begin{array}{r}1.185 * * * \\
(0.353)\end{array}$ & $\begin{array}{r}1.093 * * * \\
(0.354)\end{array}$ \\
\hline $\log ($ size $)$ & & & $\begin{array}{c}-4.508 * * * \\
(0.294)\end{array}$ & $\begin{array}{c}-3.662 * * * \\
(0.291)\end{array}$ & $\begin{array}{c}-3.582 * * * \\
(0.291)\end{array}$ \\
\hline Limited liability & & & & & $\begin{array}{r}5.828 * * * \\
(0.928)\end{array}$ \\
\hline Industry dummies (1 digit) & No & No & No & Yes & Yes \\
\hline $\mathrm{N}$ & 16,339 & 16,339 & 16,339 & 16,339 & 16,339 \\
\hline R-squared (\%) & 0.74 & 1.23 & 2.18 & 14.45 & 14.54 \\
\hline \multicolumn{6}{|l|}{ UK } \\
\hline Tangibility & $\begin{array}{r}0.073 * * * \\
(0.005)\end{array}$ & $\begin{array}{r}0.080 * * * \\
(0.005)\end{array}$ & $\begin{array}{r}0.073 * * * \\
(0.005)\end{array}$ & $\begin{array}{r}0.070 * * * \\
(0.005)\end{array}$ & $\begin{array}{r}0.070 * * * \\
(0.005)\end{array}$ \\
\hline Log(Age) & & $\begin{array}{c}-7.747 * * * \\
(0.558)\end{array}$ & $\begin{array}{c}-5.354 * * * \\
(0.569)\end{array}$ & $\begin{array}{c}-6.746^{* * *} \\
(0.583)\end{array}$ & $\begin{array}{c}-6.722 * * * \\
(0.584)\end{array}$ \\
\hline $\log ($ size $)$ & & & $\begin{array}{c}-6.580 * * * \\
(0.323)\end{array}$ & $\begin{array}{c}-5.958 * * * \\
(0.329)\end{array}$ & $\begin{array}{c}-5.923 * * * \\
(0.329)\end{array}$ \\
\hline Limited liability & & & & & $\begin{array}{c}15.149 * * * \\
(2.821)\end{array}$ \\
\hline Industry dummies (1 digit) & No & No & No & Yes & Yes \\
\hline $\mathrm{N}$ & 8,829 & 8,829 & 8,829 & 8,829 & 8,829 \\
\hline $\mathrm{R}$-squared (\%) & 2.52 & 4.30 & 7.49 & 12.76 & 12.79 \\
\hline
\end{tabular}

Dependent variable: Bankruptcy. Unconditional probabilities $=12.8 \%$ (Spain), $18.2 \%$ (France), $29.5 \%$ (UK). All regressions include a constant. Estimator: OLS. Robust standard errors in parentheses. *, **, and ***, significant at 10,5 , and $1 \%$ level

market) and firms that have been liquidated after a bankruptcy procedure (i.e., they have exited the market). The latter consists of companies that are still operating the market under financial distress and companies that exited the market while they were financially distressed. An alternative explanation for the negative impact of Tangibility 
Table 12 Marginal effects (\%) for the probability of bankruptcy in non-micro firms (2SLS)

\begin{tabular}{|c|c|c|c|c|c|}
\hline & (1) & (2) & (3) & (4) & (5) \\
\hline \multicolumn{6}{|l|}{ Spain } \\
\hline Tangibility & $\begin{array}{r}0.034 * * * \\
(0.009)\end{array}$ & $\begin{array}{r}0.025 * * * \\
(0.009)\end{array}$ & $\begin{array}{r}0.029 * * * \\
(0.009)\end{array}$ & $\begin{array}{l}0.001 \\
\quad(0.014)\end{array}$ & $\begin{array}{l}0.001 \\
\quad(0.014)\end{array}$ \\
\hline $\log ($ age $)$ & & $\begin{array}{r}2.807 * * * \\
(0.488)\end{array}$ & $\begin{array}{r}2.414 * * * \\
(0.495)\end{array}$ & $\begin{array}{r}1.164 * * \\
(0.526)\end{array}$ & $\begin{array}{c}1.177 * * \\
(0.526)\end{array}$ \\
\hline $\log ($ size $)$ & & & $\begin{array}{r}2.510 * * * \\
(0.410)\end{array}$ & $\begin{array}{r}2.717 * * * \\
(0.412)\end{array}$ & $\begin{array}{r}2.740 * * * \\
(0.413)\end{array}$ \\
\hline Limited liability & & & & & $\begin{array}{c}15,144 * * * \\
(3.062)\end{array}$ \\
\hline Industry dummies (1 digit) & No & No & No & Yes & Yes \\
\hline $\mathrm{N}$ & 11,477 & 11,462 & 11,462 & 11,462 & 11,462 \\
\hline \multicolumn{6}{|l|}{ France } \\
\hline Tangibility & $\begin{array}{r}0.281 * * * \\
(0.009)\end{array}$ & $\begin{array}{r}0.284 * * * \\
(0.010)\end{array}$ & $\begin{array}{r}0.273 * * * \\
(0.010)\end{array}$ & $\begin{array}{r}0.142 * * * \\
(0.013)\end{array}$ & $\begin{array}{r}0.144 * * * \\
(0.013)\end{array}$ \\
\hline $\log ($ age $)$ & & $\begin{array}{r}-0.677 \\
(0.447)\end{array}$ & $\begin{array}{l}0.088 \\
\quad(0.448)\end{array}$ & $\begin{array}{c}-0.256 \\
(0.397)\end{array}$ & $\begin{array}{r}-0.370 \\
(0.399)\end{array}$ \\
\hline $\log ($ size $)$ & & & $\begin{array}{c}-3.991 * * * \\
(0.344)\end{array}$ & $\begin{array}{c}-3.642 * * * \\
(0.305)\end{array}$ & $\begin{array}{c}-3.565 * * * \\
(0.306)\end{array}$ \\
\hline Limited liability & & & & & $\begin{array}{r}5.650 * * * \\
(1.048)\end{array}$ \\
\hline Industry dummies (1 digit) & No & No & No & Yes & Yes \\
\hline $\mathrm{N}$ & 16,339 & 16,339 & 16,339 & 16,339 & 16,339 \\
\hline \multicolumn{6}{|l|}{ UK } \\
\hline Tangibility & $\begin{array}{r}0.194 * * * \\
(0.022)\end{array}$ & $\begin{array}{r}0.205 * * * \\
(0.022)\end{array}$ & $\begin{array}{r}0.192 * * * \\
(0.022)\end{array}$ & $\begin{array}{r}0.131 * * * * \\
(0.025)\end{array}$ & $\begin{array}{r}0.130 * * * \\
(0.025)\end{array}$ \\
\hline Log (age) & & $\begin{array}{c}-9.382 * * * \\
(0.655)\end{array}$ & $\begin{array}{c}-7.167 * * * \\
(0.690)\end{array}$ & $\begin{array}{c}-7.775^{* * * *} \\
(0.728)\end{array}$ & $\begin{array}{c}-7.743 * * * \\
(0.730)\end{array}$ \\
\hline $\log ($ size $)$ & & & $\begin{array}{c}-5.820 * * * \\
(0.375)\end{array}$ & $\begin{array}{c}-5.536 * * * \\
(0.376)\end{array}$ & $\begin{array}{c}-5.514 * * * \\
(0.375)\end{array}$ \\
\hline Limited liability & & & & & $\begin{array}{c}11.957 * * * \\
(3.279)\end{array}$ \\
\hline Industry dummies (1 digit) & No & No & No & Yes & Yes \\
\hline $\mathrm{N}$ & 8,829 & 8,829 & 8,829 & 8,829 & 8,829 \\
\hline
\end{tabular}

Dependent variable: Bankruptcy. Unconditional probabilities $=12.8 \%$ (Spain), $18.2 \%$ (France), $29.5 \%$ (UK). All regressions include a constant. Estimator: 2SLS. Robust standard errors in parentheses. *, **, and $* * *$, significant at 10,5 , and $1 \%$ level

on the probability of filing for bankruptcy by a Spanish micro firm is that firms with high levels of tangible fixed assets relative to their levels of financial debt still have assets they may pledge as mortgage collateral to get new loans or refinance their current ones. In that case, they would avoid bankruptcy by surviving and staying in the market thanks to a private workout, rather than exiting via a foreclosure.

We have two objections to this view: one is logical; the other one is based on empirical evidence. First, in France, due the high dilution that most secured creditors suffer inside bankruptcy (see Sect. 3.2), they may be willing to make debt concessions 
in a private workout to deter the debtor from filing for bankruptcy. By contrast, secured creditors are unlikely to be held up by a debtor in Spain because, while there is an automatic stay over the enforcement of some secured credit in bankruptcy, it is very limited in time and uncertain in scope. ${ }^{41}$ In fact, the LLSV ${ }^{42}$ index (La Porta et al. 1998, updated by Djankov et al. (2007)), which measures the protection of secured creditors in bankruptcy in a scale from 0 (lowest protection) to 4 (highest), assigns 3 to Spain while 0 to France. Hence it seems implausible to explain the large differences in the bankruptcy rates of small firms in Spain and France in terms of the relative incidence of private workouts. Since those rates are low in Spain and high in France, workouts should be abundant in Spain and rare in France, while our reasoning suggests the opposite.

Second, from the empirical point of view, we address this potential criticism by keeping in the sample only those firms that exited the market. We construct a new dependent variable, bankruptcy 2 , which takes the value 1 if the firm left the market after a bankruptcy procedure and 0 otherwise. Our main results are the same: Tangibility has a negative and significant impact on the probability of being bankrupt in the case of Spanish micro firms (see Table 14). ${ }^{43}$ This effect is not present in Spanish larger firms, since the correlation is not different from zero in our OLS estimates (see Table 15) and the causal impact is not robust to several specifications in our IV estimates (see Table 16). By contrast, Tangibility has a positive impact on the probability of leaving the market after bankruptcy in the case of French firms of both size classes, while there is no effect in the case of British firms.

\section{Conclusions}

Spain had, before the current economic crisis, one of the world's lowest business bankruptcy rates, i.e., the number of business bankruptcy filings divided by the number of business exits. Only the crisis has modestly increased the number of bankruptcies, but the Spanish bankruptcy rate is still one of the lowest in the world. This fact is driven by the behaviour of micro firms - the majority of Spanish firms — which rarely file for bankruptcy when dealing with financial distress.

This paper presents and tests a hypothesis that attempts to explain this empirical finding. According to this hypothesis, filing for bankruptcy in Spain is very costly for both small firms and their creditors. Due to this, the capital structure of micro firms is biased towards mortgage loans (i.e., loans secured on land and buildings). Having this capital structure allows them to avoid bankruptcy by carrying out debt enforcement via mortgage foreclosures, which are cheaper procedures than bankruptcy, in case of financial distress.

\footnotetext{
41 The stay only involves secured credit over assets that are integrated in the debtor's production processas considered by the court-and only for 1 year or until a restructuring plan that does not affect the rights of secured creditors is approved, whichever occurs first. The law also allows the insolvency administrator to pay secured creditors out of the company's total assets during the stay.

42 La Porta, Lopez-de-Silanes, Shleifer, Vishny.

43 Notice that in the regressions of Tables 13, 14, 15 and 16 we do not include the variable Limited Liability, as in some country-size class combinations it had no variability at all, as all firms had limited liability.
} 
Table 13 Marginal effects (\%) for the probability of bankruptcy EXIT in micro firms (OLS)

\begin{tabular}{|c|c|c|c|c|}
\hline & (1) & (2) & (3) & (4) \\
\hline \multicolumn{5}{|l|}{ Spain } \\
\hline Tangibility & $\begin{array}{c}-0.072 * * * \\
(0.013)\end{array}$ & $\begin{array}{c}-0.069 * * * \\
(0.013)\end{array}$ & $\begin{array}{c}-0.070 * * * \\
(0.013)\end{array}$ & $\begin{array}{c}-0.067 * * * \\
(0.013)\end{array}$ \\
\hline Log (age) & & $\begin{array}{l}-13.669^{* * * *} \\
(2.153)\end{array}$ & $\begin{array}{l}-13.953 * * * \\
(2.140)\end{array}$ & $\begin{array}{l}-16.027 * * * \\
(2.116)\end{array}$ \\
\hline $\log ($ size $)$ & & & $\begin{array}{r}5.526 * * * * \\
(1.687)\end{array}$ & $\begin{array}{l}2.976^{*} \\
(1.710)\end{array}$ \\
\hline Industry dummies (1 digit) & No & No & No & Yes \\
\hline $\mathrm{N}$ & 1,474 & 1,474 & 1,474 & 1,474 \\
\hline Pseudo-R2 (\%) & 2.07 & 4.56 & 5.25 & 12.99 \\
\hline \multicolumn{5}{|l|}{ France } \\
\hline Tangibility & $\begin{array}{r}0.040 * * * \\
(0.012)\end{array}$ & $\begin{array}{r}0.039 * * * \\
(0.012)\end{array}$ & $\begin{array}{r}0.036 * * * \\
(0.012)\end{array}$ & $\begin{array}{l}0.017 \\
\quad(0.012)\end{array}$ \\
\hline Log (age) & & $\begin{array}{l}-7.709 * * * \\
(1.332)\end{array}$ & $\begin{array}{c}-7.990 * * * \\
(1.346)\end{array}$ & $\begin{array}{c}-6.349 * * * \\
(1.343)\end{array}$ \\
\hline $\log ($ size $)$ & & & $\begin{array}{l}2.600^{*} \\
(1.393)\end{array}$ & $\begin{array}{r}-0.756 \\
(1.432)\end{array}$ \\
\hline Industry dummies (1 digit) & No & No & No & Yes \\
\hline $\mathrm{N}$ & 2,220 & 2,220 & 2,220 & 2,220 \\
\hline Pseudo-R2 (\%) & 0.52 & 2.10 & 2.26 & 10.62 \\
\hline \multicolumn{5}{|l|}{ UK } \\
\hline Tangibility & $\begin{array}{r}0.038 * * * \\
(0.009)\end{array}$ & $\begin{array}{r}0.033 * * * \\
(0.008)\end{array}$ & $\begin{array}{r}0.032 * * * \\
(0.008)\end{array}$ & $\begin{array}{r}0.033 * * * \\
(0.009)\end{array}$ \\
\hline Log (age) & & $\begin{array}{r}5.551 * * * \\
(1.931)\end{array}$ & $\begin{array}{r}5.562 * * * \\
(1.927)\end{array}$ & $\begin{array}{r}5.667 * * * \\
(1.872)\end{array}$ \\
\hline $\log ($ size $)$ & & & $\begin{array}{l}3.904 \\
(3.704)\end{array}$ & $\begin{array}{l}3.058 \\
(3.876)\end{array}$ \\
\hline $\begin{array}{l}\text { Industry dummies (1 digit) } \\
\mathrm{N}\end{array}$ & $\begin{array}{l}\text { No } \\
636\end{array}$ & $\begin{array}{l}\text { No } \\
636\end{array}$ & $\begin{array}{l}\text { No } \\
636\end{array}$ & $\begin{array}{l}\text { Yes } \\
636\end{array}$ \\
\hline Peeudo-R2 (\%) & 1.99 & 3.17 & 3.39 & 9.15 \\
\hline
\end{tabular}

Dependent variable: Bankruptcy. Unconditional probabilities $=61.8 \%$ (Spain), $77.3 \%$ (France), $89.8 \%$ (UK). All regressions include a constant. Estimator: OLS. Robust standard errors in parentheses. *, **, and $* * *$, significant at 10,5 , and $1 \%$ level

To test this hypothesis our identification strategy relies on cross-country comparisons. Specifically, we compare the observed choices (choice of capital structure, choice between bankruptcy and mortgage) of Spanish firms with those of firms from countries where their bankruptcy systems are more efficient and their laws do not incentivise them to bias their capital structure towards mortgage loans. France and the UK are chosen as the comparison group because their bankruptcy rates are much higher than the Spanish ones and because of the specific features of their insolvency frameworks.

Our findings corroborate the proposed hypothesis. First, there is a positive and strong correlation between the ex-ante probability of default and the ratio of tangible 
Table 14 Marginal effects (\%) for the probability of bankruptcy EXIT in micro firms (2SLS)

\begin{tabular}{|c|c|c|c|c|}
\hline & (1) & (2) & (3) & (4) \\
\hline \multicolumn{5}{|l|}{ Spain } \\
\hline Tangibility & $\begin{array}{c}-0.119 * * * \\
(0.034)\end{array}$ & $\begin{array}{c}-0.112 * * * \\
(0.035)\end{array}$ & $\begin{array}{c}-0.125 * * * \\
(0.036)\end{array}$ & $\begin{array}{c}-0.146 * * * \\
(0.036)\end{array}$ \\
\hline Log (age) & & $\begin{array}{c}-13.383^{* * * *} \\
(2.179)\end{array}$ & $\begin{array}{c}-13.603 \text { *** } \\
(2.173)\end{array}$ & $\begin{array}{c}-15.496 * * * \\
(2.167)\end{array}$ \\
\hline $\log ($ size $)$ & & & $\begin{array}{r}5.750 * * * \\
(1.693)\end{array}$ & $\begin{array}{l}2.855^{*} \\
\quad(1.726)\end{array}$ \\
\hline Industry dummies (1 digit) & No & No & No & Yes \\
\hline $\mathrm{N}$ & 1,474 & 1,474 & 1,474 & 1,474 \\
\hline \multicolumn{5}{|l|}{ France } \\
\hline Tangibility & $\begin{array}{r}0.283 * * * \\
(0.049)\end{array}$ & $\begin{array}{r}0.277 * * * \\
(0.048)\end{array}$ & $\begin{array}{r}0.280 * * * \\
(0.051)\end{array}$ & $\begin{array}{l}0.074 \\
\quad(0.047)\end{array}$ \\
\hline Log (age) & & $\begin{array}{c}-7.334 * * * \\
(1.453)\end{array}$ & $\begin{array}{c}-7.254 * * * \\
(1.491)\end{array}$ & $\begin{array}{c}-6.245^{* * *} * \\
(1.350)\end{array}$ \\
\hline $\log ($ size $)$ & & & $\begin{array}{r}-0.707 \\
(1.649)\end{array}$ & $\begin{array}{r}-1.329 \\
(1.507)\end{array}$ \\
\hline Industry dummies (1 digit) & No & No & No & Yes \\
\hline $\mathrm{N}$ & 2,220 & 2,220 & 2,220 & 2,220 \\
\hline \multicolumn{5}{|l|}{ UK } \\
\hline Tangibility & $\begin{array}{r}0.080 * * * \\
(0.028)\end{array}$ & $\begin{array}{r}0.077 * * * \\
(0.028)\end{array}$ & $\begin{array}{l}0.073 * * \\
(0.029)\end{array}$ & $\begin{array}{l}0.068 * \\
(0.035)\end{array}$ \\
\hline Log (age) & & $\begin{array}{l}4.277 * * \\
(2.100)\end{array}$ & $\begin{array}{l}4.378 * * \\
(2.092)\end{array}$ & $\begin{array}{l}4.742 * * \\
\quad(2.016)\end{array}$ \\
\hline $\log ($ size $)$ & & & $\begin{array}{l}2.520 \\
\quad(3.829)\end{array}$ & $\begin{array}{l}2.098 \\
\quad(3.956)\end{array}$ \\
\hline Industry dummies (1 digit) & No & No & No & Yes \\
\hline $\mathrm{N}$ & 636 & 636 & 636 & 636 \\
\hline
\end{tabular}

Dependent variable: Bankruptcy. Unconditional probabilities $=61.8 \%$ (Spain), $77.3 \%$ (France), $89.8 \%$ (UK). All regressions include a constant. Estimator: 2SLS. Robust standard errors in parentheses. *, **, and $* * *$, significant at 10,5 , and $1 \%$ level

fixed assets (the assets that can be pledged as mortgage collateral) to financial debt in the case of Spanish micro firms, suggesting that firms with risky business models bias their capital structure towards mortgage loans to avoid filing for bankruptcy in the event of default. Second, a higher proportion of tangible fixed assets over financial debt significantly decrease the probability of being in bankruptcy among Spanish micro firms in financial distress. By contrast, these two relations do not hold either for Spanish larger businesses or for firms from the other two countries.

We must stress the importance of the research question. Bankruptcy procedures and mortgage foreclosures are not perfect substitutes, and the underutilization of one of them-reflected in low bankruptcy rates - may lead to efficiency losses and lower welfare (García-Posada 2013). The reason is that the mortgage system is not well suited for some firms, which need to bias their asset structure to have enough collateral, with the ensuing productive inefficiencies. Those firms would be better off if they had access to 
Table 15 Marginal effects (\%) for the probability of bankruptcy EXIT in non-micro firms (OLS)

\begin{tabular}{|c|c|c|c|c|}
\hline & (1) & (2) & (3) & (4) \\
\hline \multicolumn{5}{|l|}{ Spain } \\
\hline Tangibility & $\begin{array}{l}0.010 \\
\quad(0.025)\end{array}$ & $\begin{array}{l}0.008 \\
\quad(0.024)\end{array}$ & $\begin{array}{l}0.008 \\
\quad(0.024)\end{array}$ & $\begin{array}{l}0.022 \\
\quad(0.020)\end{array}$ \\
\hline Log (age) & & $\begin{array}{r}8.497 * * * \\
(2.793)\end{array}$ & $\begin{array}{r}8.575^{* * * *} \\
(2.814)\end{array}$ & $\begin{array}{l}0.511 \\
\quad(2.902)\end{array}$ \\
\hline $\log ($ size $)$ & & & $\begin{array}{c}-1.288 \\
(2.703)\end{array}$ & $\begin{array}{c}-0.384 \\
\quad(2.441)\end{array}$ \\
\hline Industry dummies (1 digit) & No & No & No & Yes \\
\hline $\mathrm{N}$ & 544 & 544 & 544 & 544 \\
\hline Pseudo R2 (\%) & 0.03 & 1.75 & 1.79 & 23.44 \\
\hline \multicolumn{5}{|l|}{ France } \\
\hline Tangibility & $\begin{array}{r}0.033^{* * * *} \\
(0.012)\end{array}$ & $\begin{array}{r}0.036 * * * \\
(0.012)\end{array}$ & $\begin{array}{r}0.038 * * * \\
(0.012)\end{array}$ & $\begin{array}{l}0.023^{*} \\
(0.012)\end{array}$ \\
\hline Log (age) & & $\begin{array}{c}-4.621 * * * \\
(1.517)\end{array}$ & $\begin{array}{c}-3.908 * * \\
(1.525)\end{array}$ & $\begin{array}{c}-4.157^{* * * *} \\
(1.509)\end{array}$ \\
\hline $\log ($ size $)$ & & & $\begin{array}{c}-6.722 * * * \\
(1.697)\end{array}$ & $\begin{array}{c}-5.648^{* * *} \\
(1.694)\end{array}$ \\
\hline Industry dummies (1 digit) & No & No & No & Yes \\
\hline $\mathrm{N}$ & 1,635 & 1,635 & 1,635 & 1,635 \\
\hline Pseudo R2 (\%) & 0.42 & 1.05 & 2.16 & 11.88 \\
\hline \multicolumn{5}{|l|}{ UK } \\
\hline Tangibility & $\begin{array}{r}0.032 * * * \\
(0.005)\end{array}$ & $\begin{array}{r}0.029 * * * \\
(0.005)\end{array}$ & $\begin{array}{r}0.030 * * * \\
(0.005)\end{array}$ & $\begin{array}{r}0.030 * * * \\
(0.005)\end{array}$ \\
\hline Log (age) & & $\begin{array}{r}6.429 * * * \\
(0.942)\end{array}$ & $\begin{array}{r}6.337 * * * \\
(0.944)\end{array}$ & $\begin{array}{r}5.202 * * * \\
(0.973)\end{array}$ \\
\hline $\log ($ size $)$ & & & $\begin{array}{l}0.626 \\
(0.743)\end{array}$ & $\begin{array}{c}1.587 * * \\
(0.768)\end{array}$ \\
\hline Industry dummies (1 digit) & No & No & No & Yes \\
\hline $\mathrm{N}$ & 1,862 & 1,862 & 1,862 & 1,862 \\
\hline Pseudo R2 (\%) & 1.65 & 3.91 & 3.94 & 6.38 \\
\hline
\end{tabular}

Dependent variable: Bankruptcy. Unconditional probabilities $=76.1 \%$ (Spain), $76.3 \%$ (France), $91.3 \%$ (UK). All regressions include a constant. Estimator: OLS. Robust standard errors in parentheses. *, **, and $* * *$, significant at 10,5 , and $1 \%$ level

a bankruptcy system that worked relatively well. If the absence of a well-functioning bankruptcy system for those firms also reduces their growth opportunities-e.g., by hampering access to unsecured lending such as venture capital-then the current insolvency framework may help explain the firm size distribution and the low aggregate productivity of the Spanish economy. This is consistent with the evidence of Fabbri (2010) in Spain, who finds that lengthy bankruptcy procedures decrease firm size and raise funding costs and with that of Ponticelli (2012) in Brazil, who shows that congestion in bankruptcy courts substantially reduces firm-level investment and productivity.

This paper is a first step towards understanding how agents respond to the Spanish insolvency framework and their implications for the real economy. Further work is 
Table 16 Marginal effects (\%) for the probability of bankruptcy EXIT in non-micro firms (2SLS)

\begin{tabular}{|c|c|c|c|c|}
\hline & (1) & (2) & (3) & (4) \\
\hline \multicolumn{5}{|l|}{ Spain } \\
\hline Tangibility & $\begin{array}{r}-0.013 \\
(0.058)\end{array}$ & $\begin{array}{r}-0.021 \\
(0.058)\end{array}$ & $\begin{array}{r}-0.023 \\
(0.058)\end{array}$ & $\begin{array}{r}-0.090 \\
(0.073)\end{array}$ \\
\hline Log (age) & & $\begin{array}{r}8.574 * * * \\
(2.802)\end{array}$ & $\begin{array}{r}8.671 * * * \\
(2.823)\end{array}$ & $\begin{array}{l}0.344 \\
\quad(2.957)\end{array}$ \\
\hline $\log ($ size $)$ & & & $\begin{array}{r}-1.534 \\
(2.728)\end{array}$ & $\begin{array}{r}-1.064 \\
(2.492)\end{array}$ \\
\hline Industry dummies (1 digit) & No & No & No & Yes \\
\hline $\mathrm{N}$ & 544 & 544 & 544 & 544 \\
\hline \multicolumn{5}{|l|}{ France } \\
\hline Tangibility & $\begin{array}{r}0.135 * * * \\
(0.039)\end{array}$ & $\begin{array}{r}0.143 * * * \\
(0.040)\end{array}$ & $\begin{array}{r}0.149 * * * \\
(0.040)\end{array}$ & $\begin{array}{l}0.055 \\
\quad(0.044)\end{array}$ \\
\hline Log (age) & & $\begin{array}{c}-5.409 * * * \\
(1.573)\end{array}$ & $\begin{array}{c}-4.644 * * * \\
(1.580)\end{array}$ & $\begin{array}{c}-4.302 * * * \\
(1.516)\end{array}$ \\
\hline $\log ($ size $)$ & & & $\begin{array}{c}-7.406 * * * \\
(1.707)\end{array}$ & $\begin{array}{c}-5.877 * * * \\
(1.712)\end{array}$ \\
\hline Industry dummies (1 digit) & No & No & No & Yes \\
\hline $\mathrm{N}$ & 1,635 & 1,635 & 1,635 & 1,635 \\
\hline \multicolumn{5}{|l|}{ UK } \\
\hline Tangibility & $\begin{array}{l}0.017 \\
\quad(0.018)\end{array}$ & $\begin{array}{l}0.015 \\
\quad(0.018)\end{array}$ & $\begin{array}{l}0.016 \\
\quad(0.018)\end{array}$ & $\begin{array}{l}0.027 \\
\quad(0.018)\end{array}$ \\
\hline Log (age) & & $\begin{array}{r}6.625 * * * \\
(1.000)\end{array}$ & $\begin{array}{r}6.542 * * * \\
(1.008)\end{array}$ & $\begin{array}{r}5.250 * * * \\
(1.017)\end{array}$ \\
\hline $\log ($ size $)$ & & & $\begin{array}{l}0.535 \\
\quad(0.750)\end{array}$ & $\begin{array}{l}1.561 * * \\
(0.771)\end{array}$ \\
\hline Industry dummies (1 digit) & No & No & No & Yes \\
\hline $\mathrm{N}$ & 1,862 & 1,862 & 1,862 & 1,862 \\
\hline
\end{tabular}

Dependent variable: Bankruptcy. Unconditional probabilities $=76.1 \%$ (Spain), $76.3 \%$ (France), $91.3 \%$ (UK). All regressions include a constant. Estimator: 2SLS. Robust standard errors in parentheses. *, **, and $* * *$, significant at 10,5 , and $1 \%$ level

required in two directions. First, better data without the limitations of our sample, especially regarding information on mortgage loans and the alternative procedures to formal bankruptcy, could be collected. Second, the impact of the low efficiency of the bankruptcy system vis-à-vis mortgage foreclosures on the performance of Spanish firms should be empirically analyzed.

Open Access This article is distributed under the terms of the Creative Commons Attribution License which permits any use, distribution, and reproduction in any medium, provided the original author(s) and the source are credited. 


\section{Appendix A: Legal terminology related to insolvency procedures, secured lending and foreclosures under Spanish, English and French Law}

\section{A.1 Some preliminary clarifications}

Legal terms are difficult to translate and do not have exact equivalents in different legal systems. Basic concepts such as a "floating charge" (under English Law) have not a direct translation into Spanish Law or French Law. Furthermore, Spanish or French Law basic terms like hipoteca ${ }^{44}$ or hypothèque $e^{45}$ cannot be unambiguously translated as "mortgage" in the British law. This appendix attempts to clarify the main concepts used in this paper.

In all cases, we define "insolvency" as a situation in which the debtor is unable to pay debts when they are due (cash-flow insolvency). ${ }^{46}$ This situation is known in French law as cessation de paiements or faillite and in Spanish Law as quiebra or bancarrota. In this appendix we focus on the analysis of insolvency once that insolvency situation has been formally recognized. Previously, the debtor could have tried to reach an out-of-court arrangement or private workout with its creditors by which the creditors could accept less than the full amount (or in some cases, the full amount, if it can be determined without the aid of any legal proceeding) they are owed. If those arrangements fail or they are not even attempted, in Spain there is a formal procedure to resolve an insolvency situation called concurso de acreedores. In this paper the Spanish procedure is compared with the main procedures for corporate insolvency in France (the redressement judiciare ${ }^{47}$ - a reorganisation procedure- and the liquidation judiciare - a liquidation one ${ }^{48}$ ) and in the UK (administration and, before 2003, administrative receivership). ${ }^{49}$

The Spanish bankruptcy system (Ley Concursal), which entered into force in $2004,{ }^{50}$ applied to consumers and all types of firms, including both limited liability companies and personally owned businesses with no limit to personal liability. In September 2013 the Spanish Parliament approved some legal reforms in this regard that are summarised in Appendix A.6. By contrast, there are specific procedures for personal debtors both in France and the UK, which may be used by consumers, selfemployed individuals and owners of small firms that used personal guarantees to

\footnotetext{
44 In Spanish law, Article 1874 et seq of the Spanish Civil Code.

45 Articles 2393 et seq of the French Civil Code.

46 See Armour (2001) for a discussion on the different types of insolvency.

47 Law 2005-845 of July 26, 2005 "de sauvegarde des enterprises".

48 A new procedure, the sauvegarde, was introduced in the latest reform of the bankruptcy code (Loi de sauvegarde des entreprises), which came became effective in 2006. In addition, the parties have the possibility to recur to a mandataire ad hoc, a process by which a court-appointed mediator assists in nonbinding negotiations between a debtor and its creditors and to a réglement amiable, a judicially supervised negotiation procedure in which the court may grant a stay against creditors.

49 Other (much less used) procedures are company voluntary arrangements - a reorganisation procedurecompulsory liquidation and creditors' voluntary liquidations.

50 The current Act has been modified three times, in March 2009, in October 2011 and in March 2014, in order to solve various dysfunctional features in the initial design. For instance, formal workout negotiations on the brink of bankruptcy filing have been facilitated.
} 
fund their businesses. France has two procedures, the plan de redressement and the procedure de rétablissement personnel, while bankruptcy is the main insolvency procedure for individuals in the UK. ${ }^{51}$ It is necessary to remark that, in the UK, the term "bankruptcy" only applies to individuals, while insolvency is the term that is used for companies. Once taken into account this legal notice, we must note that the term bankruptcy is used in this paper as a general term to denote formal insolvency procedures in general (as used in American Standard English).

\section{A.2 The equivalents in Spanish and French law of the UK insolvency proceedings}

In the UK the main corporate insolvency procedure is called administration. Administrative receivership is not available from September 15, 2003 (although, of course, we could still observe some few active cases) due to the adoption of the Enterprise Act 2002. This case is discussed separately in Appendix A.4.

In the case of administration, an administrator is appointed and tries to reach a better outcome for creditors than the one that could be achieved in a liquidation by the debtor. The administration is requested before a judge by the insolvent company or its creditors. If the judge deems that there is actually a situation of insolvency, she will issue an administration order. It is very important to note that the holder of a floating charge (a concept explained below) can appoint an administrator even without court order. This administrator, however, will take care of the interests of all creditors (and not only of the floating charge holder, unlike in the administrative receivership procedure, see Appendix A.4).

As it was mentioned, the procedures closer to administration in French and Spanish Law are, respectively, the redressement judiciare and the concurso de acreedores. In all these cases there is judicial supervision of the procedures and the judge may appoint an administrator for the insolvent company. ${ }^{52}$

A.3 The equivalents in Spanish and French law of the security interests in the UK law

\section{A.3.1 Fixed charge}

A fixed charge is defined over a determined (specific) movable or immovable property. That is, the goods secured by a fixed charge must be clearly identifiable (in contrast to the floating charge).

There are several types of fixed charges in English Law: mortgage over land and buildings owned by the company, chattels mortgage and the charge against goodwill and other intellectual property rights.

The first type of fixed charge is the one that is closest to what in Spanish law we call hipoteca (which is a derecho real, a real right). It is regulated by articles 1874 et

\footnotetext{
51 Bankruptcy in Scotland is referred to as "sequestration". Other personal insolvency procedures in England, Wales and Northern Ireland are individual voluntary arrangements and debt relief orders, while another one in Scotland is a "protected trust deed".

52 This last circumstance only occurs in some specific cases in French law (in which the judge appoints an administrateur judiciaire).
} 
seq of the Spanish Civil Code. The figure is close to the hypothèque in French law (articles 2393 et seq of the French Civil Code). When there is a hipoteca or equivalent figures, the ownership of the property remains to the buyer, but there is a charge over that property right which disappears only when the loan has been repaid.

In the case of a chattels mortgage, the purchaser borrows funds for the purchase of movable property (the chattel). The lender secures the loan with a mortgage over the chattel. Legal ownership of the chattel is transferred to the purchaser at the time of purchase, and the mortgage is removed once the loan has been repaid.

Potentially similar legal figures exist in Spanish law as the prenda ${ }^{53}$ (which is also a derecho real) or the prenda sin desplazamiento and hipoteca mobiliaria governed by the Ley de Hipoteca mobiliaria y prenda sin desplazamiento ${ }^{54}$ (thus out of the Spanish Civil Code). Also potentially similar concepts exist in French Law, such as the gage and the nantissement. 55

As a result, hipoteca and mortgage are not directly interchangeable terms. Mortgage in English law would identify a set of guarantees/securities on goods that could be, roughly, the derechos reales (real rights) in continental law (Spanish and French Law, in this paper). To avoid confusion, in this paper we identify what we call hipoteca in Spain as mortgage over land and buildings (for brevity of exposition, just mortgage), i.e., the first type of fixed charge discussed in this section.

\section{A.3.2 Floating charge}

Unlike the fixed charge (and its specificities), the floating charge has no strict equivalent in Spanish or French law. The Civil Code in both countries requires that the secured assets must be clearly identifiable. However, one would talk about some similarities in the case of the prenda sin desplazamiento of the Spanish law. ${ }^{56}$

A floating charge is a security interest over a fund of changing assets ${ }^{57}$ of a firm that "floats" until it "crystallises" (converts) into a fixed charge, at which point the charge attaches to specific assets. The crystallisation can be triggered by a number of events, being one of them the borrower's default. In other words, the "floating charge" is public and takes effect only when the company has failed to fulfil its obligations. The main difference of the floating charge relative to other security interests such as the fixed charge is that, because the security "floats", the firm remains free to purchase and sell assets. That is, the company remains in possession of the property and can dispose of it in the normal course of business.

Unlike traditional collateral (derechos reales, as explained above) in Civil Law, the floating charge covers not only present property but also the future property of the

\footnotetext{
53 Article 1863 et seq of the Spanish Civil Code.

54 Ley de hipoteca mobiliaria y prenda sin desplazamiento of December 16, 1954.

55 Articles 2333 et seq of the French Civil Code in the first case and 2355 and subsequent articles in the second case.

56 In other Spanish-speaking or French-speaking legal systems and with evident influence of both continental and Anglo-Saxon Law, we could find legal figures such as the charge flottante (nantissement flottante) of the Canadian Law and the prenda flotante that exists in some American legal systems.

57 For this reason, this legal figure may be "translated" in Spanish, not into Spanish law, as prenda rotativa.
} 
debtor (including future cash flows), while giving the debtor the right to dispose of it. At the time of the crystallization, the "floating" charge is fixed and the beneficiary may then exercise its rights over it. ${ }^{58}$ The floating charge is based on property that has not already been specifically mortgaged or pledged.

In summary, compared to the flexibility of the floating charge (that is not related to any good in particular until there is a crystallization as a result of the insolvency of the debtor), the derechos reales (hipotecas, prendas, etc) in Spain are specific in nature. The hipoteca, for example, is a security that gives its holder an immediate and direct right over immovable property (mainly land and buildings) that can be exercised and made effective against any other creditor. The prenda, meanwhile, is a security that gives the holder a right over movable property.

\section{A.4 Administrative receivership}

Although, as noted before, this procedure is no longer available, there are still some (few) active cases. In administrative receivership the holder of a floating charge on the business, commonly one bank providing the bulk of finance to the company, could appoint, with almost no other constraints, as soon as there was a default in the loan, a receiver who would take over the entire company, assumed all the powers of the company's board of directors and would try to maximise recovery for the holder of the floating charge ${ }^{59}$.

Naturally, this procedure did not prevent other creditors from exercising their right to judicial oversight of the debtor's insolvency. However, the floating charge holder had the ability to veto other procedures, particularly the administration, if he appointed an administrative receiver. As it was noted, after the disappearance of the administrative receivership procedure (after September 15, 2003), judicial supervision (through the process of administration) has become the standard way to proceed in UK Law.

\section{A.5 Foreclosures, ejecuciones prendarias and related procedures}

As it was introduced above, in Spain a creditor may secure a loan, among other options, through a contract of prenda (over movable property), a hipoteca (on immovable assets) and other legal figures with characteristics of one or the other (hipoteca mobiliaria, prenda sin desplazamiento). All these contracts are forms of real rights (derechos reales) as the good is well identified (in all these cases we would be talking about mortgages under UK Law, included under the category of fixed charges).

Both the prenda and the hipoteca must appear in a public document that facilitates execution (if needed). Moreover, in the case of the hipoteca, the Spanish Law also requires to be registered in the land registry. The creditor, in the event of loan default by the debtor, may proceed to execute its right over the property (the acción hipotecaria

\footnotetext{
58 The crystallization has the effect of designating the property referred to and make it enforceable against third parties.

59 This normally did not imply piecemeal liquidation of the assets, but the sale of the business to a new entrepreneur.
} 
if there was a hipoteca contract and acción prendaria o pignoraticia if there was a prenda). In Spain, in both cases the creditor may recourse to a judicial enforcement (if performed by a judge) or an out of court enforcement (if performed by a notary).

The judicial enforcement ${ }^{60}$, both in the case of prendas and hipotecas, is regulated by the Civil Procedural Law and establishes an auction with various guarantees to the parties. The extrajudicial execution ${ }^{61}$, whether in either case, is done before a notary also by auction (with citation of the debtor and the owner of the prenda where applicable).

In the UK there is the so-called foreclosure, which could be defined as a debt enforcement procedure aimed at recovering money owed to secured creditors (Djankov et al. 2008). Derived from the above definition we must directly rule out a direct legal equivalence between foreclosure and ejecución oracción hipotecaria. That is, we must be very specific when using these terms. Therefore, we should "translate" ejecución de un bien mueble pignorado (acción pignoraticia) as a foreclose on a pledged movable asset under UK Law. Then, if the property is an immovable asset (e.g. a building, a plant, the entrepreneur's home), we could use the term "mortgage over land and buildings" foreclosures in the case of an execution (acción hipotecaria in Spain). In the main text we simplify the terminology and, for brevity of exposition, we use the term mortgage foreclosure.

Alongside the Spanish case, in France we can find a droit réel de gage or nantissement on (tangible or intangible) movable property (the closest Spanish legal concept is therefore the prenda) and a hypothèque on immovable property (the closest Spanish figure, as it was discussed, would be the hipoteca). The French enforcement procedure in the case of immovable property (saisie immobilière) differs with respect to that in Spain, in the fact that judicial intervention is always needed. The judicial intervention will take place either via a huissier (bailiff) or the enforcement judge directly (juge d'exécution). Like in Spain, the execution of fixed charge/security over a movable property (mise à exécution d'un gage ou d'un nantissement) can be either judicial or extrajudicial. $^{62}$

The specific rules governing the executions of fixed charges over immovable property assets can be found in the Code des procédures civiles d'exécution ${ }^{63}$ and its regulations. The execution (procédure of saisie immobilière) takes place after the proper formal notifications to the debtor. In this procedure, as in Spain, there may be a forced sale of the (immovable/land, buildings, etc) mortgaged property (vente forcée) by auction (vente aux enchères) if it was not possible to do it in another way (vente amiable).

\footnotetext{
60 Regulated in the article 681 et seq of the Civil Procedural Law of Spain. Law 1/2000, of January 7, de Enjuiciamiento Civil.

${ }^{61}$ Governed by article 1872 of the Spanish Civil Code in the case of movable property and article 222 et seq of the Reglamento para la Ejecución de la Ley Hipotecaria (Decree of February 14, 1947) if the property was secured by a hipoteca.

62 Articles 2347 and 2355 of the French Civil Code respectively.

63 The specific rules in these cases can be found in the Code des procédures civiles d'exécution (Title II, Articles L.311-1 to L.322-14 and Title III) and its regulations.
} 


\section{A.6 Recent developments in Spanish Law}

Until very recently, in Spain the insolvency procedures available for self-employed individuals and entrepreneurs (i.e., managers/owners of small firms) were governed by the same rules than in the case of large businesses such as a limited liability companies. In September 2013 the Spanish Parliament approved a law that will create some sort of special bankruptcy regime for them. ${ }^{64}$ The law contemplates introducing some limitation of the liability of the entrepreneur / self-employed individual through the new figure of entrepreneur with limited liability (emprendedor de responsabilidad limitada). This figure will allow that part of the assets of the entrepreneur will be exempted in case of insolvency, namely EUR 300,000 invested in its primary residence. The law also introduces a partial "fresh start": the entrepreneur will be discharged of her pre-bankruptcy debts as longs as she pays in full the preferential, secured and privileged credit and at least a $25 \%$ of the ordinary credit. ${ }^{65}$ Finally, the law establishes a new insolvency procedure, the acuerdo extrajudicial de pagos, an extrajudicial debt workout coordinated by a public mediator. If no agreement is reached between the debtor and her creditors, a judicial bankruptcy procedure (concurso consecutivo) will follow, but the negotiation attempt will increase the fresh start: no ordinary credit will have to be reimbursed.

We must keep in mind that in Spain, as a general rule, it is not possible to apply a principle of limited liability to the debtor (that is, legally release the debtor from its debts, fully or partially, when it cannot pay). This is the so-called "principle of universal liability" (article 1911 of the Civil Code) ${ }^{66}$ that states that the debtor responds with all present and future assets to the fulfilment of its obligations.

The process of ejecución hipotecaria has also undergone some reforms very recently (2013) which we should summarise here but do not affect the results of this paper either. In parallel to the debate on the judgment "Aziz vs CatalunyaCaixa" ${ }^{67}$ the Law 1/2013 opens avenues to override clauses that impose "excessive" interest rates to the debtor, through a reform of the Ley Hipotecaria. ${ }^{68}$ The reform also increases from one to three the minimum number of payments that must be missed before the foreclosure process can be started and it allows suspending for two years the evictions of debtors when they are considered to be especially vulnerable. It also reformed the auction process by amending the Civil Procedure Act. Specifically, it has lowered the security required to tenderers.

\footnotetext{
64 Ley 14/2013, de 27 de septiembre, de apoyo a los emprendedores y su internacionalización.

65 Preferential credit (créditos contra la masa) comprises salaries for the last month of activity, the costs of the procedure itself, including compensation for the insolvency administrators, plus the new debt incurred by the firm in its activities after the insolvency declaration. Privileged credit (créditos con privilegio general) mainly comprises other labour credits, tax debts and social security contributions.

66 Also articles 605 to 607 of the Civil Procedural Law.

67 Judgment in Case C-415/11 of the Court of Justice of the European Union.

68 Article 3 of Law 1/2013, of May 14, de medidas para reforzar la protección a los deudores hipotecarios, reestructuración de deuda y alquiler social.
} 
Table 17 Number of micro firms and \% over the total number of distressed firms

\begin{tabular}{llll}
\hline & Spain & France & UK \\
\hline Unweighted sample & 47,710 & 47,861 & 2,387 \\
& $80.6 \%$ & $74.6 \%$ & $21.3 \%$ \\
Weighted sample & 44,189 & 42,497 & 2,048 \\
& $93.3 \%$ & $92.9 \%$ & $87.9 \%$ \\
\hline
\end{tabular}

\section{Appendix B: Robustness analysis of the Ex-Post perspective: weighted sample of distressed firms}

Since Orbis is a commercial database, our sample may not be representative of the whole population of Spanish, French and British firms. This may be especially problematic for distressed firms because of the rarity of bankruptcy filings and for micro firms because of their low coverage in databases on firm annual accounts. In order to increase the representativeness and external validity of our results we construct sampling weights using data from the OECD's Structural and Demographic Business Statistics (SDBS) and the Spanish Statistical Institute (INE). SDBS provides the distribution of enterprises in each economy by detailed industrial sector (up to 4-digit level) and by size class, ${ }^{69}$ while INE has the distribution of Spanish bankrupt firms by size and industry ${ }^{70}$ Hence, by weighting our observations we can correct sampling biases. A caveat of this approach is that, since the SDBS does not have information on some industries, ${ }^{71}$ we must throw away some firms, ending up with around 136,000 observations of distressed firms.

Table 17 shows the number and percentage over the total number of distressed companies of micro firms, by country, for both samples. Those percentages are somewhat higher in the weighted sample in the case of Spain and France, while they are dramatically higher in the UK, indicating that micro firms are underrepresented in the unweighted sample, especially in the UK.

Table 18 shows the number and percentage over the total number of distressed companies of bankrupt firms, by country and by size, of both samples. In the case of the unweighted sample, although the percentage of bankrupt firms is the lowest for Spain, the differences relative to France and the UK are much smaller than the differences in bankruptcy rates reported in the introduction (see Table 1). However, this is not longer the case in the weighted sample, where the percentages of bankrupt firms in France and the UK are more than 60 times larger than that of

\footnotetext{
69 The size class breakdowns, according to the number of employees, are: 1-9, 10-19, 20-49, 50-249, 250 or more.

${ }^{70}$ Unfortunately we did not have analogous information on French and British firms. However, the examination of the sample (see below) revealed that the main source of sampling bias was the case of Spanish bankrupt firms.

71 Specifically, the SDBS has no information on the following industries (ISIC Rev. 3): Agriculture, hunting and forestry; Fishing; Financial Intermediation; Education; Health and social work; Other community, social and personal service activities.
} 
Table 18 Number of bankrupt firms and \% over the total number of distressed firms

\begin{tabular}{|c|c|c|c|}
\hline & Spain & France & UK \\
\hline \multicolumn{4}{|c|}{ Panel A: unweighted sample } \\
\hline \multirow[t]{2}{*}{ All firms } & 3,182 & 7,988 & 3,354 \\
\hline & $5.4 \%$ & $12.4 \%$ & $29.9 \%$ \\
\hline \multirow[t]{2}{*}{ Micro } & 1,713 & 5,023 & 753 \\
\hline & $3.6 \%$ & $10.5 \%$ & $31.6 \%$ \\
\hline \multirow[t]{2}{*}{ Non-micro } & 1,469 & 2,965 & 2,601 \\
\hline & $12.8 \%$ & $18.2 \%$ & $29.5 \%$ \\
\hline \multicolumn{4}{|c|}{ Panel B:weighted sample } \\
\hline \multirow[t]{2}{*}{ All firms } & 3,052 & 7,431 & 3,040 \\
\hline & $0.2 \%$ & $12.8 \%$ & $36.6 \%$ \\
\hline \multirow[t]{2}{*}{ Micro } & 1,642 & 4,643 & 674 \\
\hline & $0.1 \%$ & $12.4 \%$ & $36.5 \%$ \\
\hline \multirow[t]{2}{*}{ Non-micro } & 1,410 & 2,788 & 2,366 \\
\hline & $1.1 \%$ & $17.9 \%$ & $37.7 \%$ \\
\hline
\end{tabular}

Spain, in line with the differences in bankruptcy rates, and the percentage of Spanish micro firms under bankruptcy is much lower than that of their non-micro counterparts, also in line with the aggregate evidence. Hence the oversampling of Spanish bankrupt firms in the unweighted sample enhances the internal validity of our estimations because, given the rarity of bankruptcy filings, a simple random sample will not yield enough bankruptcies to implement statistical analyses, while the correction of this sampling bias with the weighted sample ensures the external validity of our results.

Let us now, as in Sect. 5.2, study the relationship between capital structure and probability of bankruptcy. Table 19 shows, again as a benchmark, the results of OLS estimation for the probability of bankruptcy of a micro firm using sampling weights. Comparing it with Table 9 (no weights) we can see that results are remarkably similar for Spanish firms: there is a negative and significant correlation between Tangibility and the probability of bankruptcy, which is robust to all specifications. The correlation is positive and significant in the case of the UK, as it was in the unweighted sample. By contrast, the conclusions do change for French firms: now such a relationship is not statistically different from zero in any specification.

In the case of the consistent IV estimates, Table 20 corroborates the findings of Table 10 (unweighted sample). Tangibility has a negative impact on the probability of bankruptcy of a Spanish micro firm. The effect is statistically and economically significant: a $1 \%$ increase in Tangibility decreases that probability by around $0.002 \%$. As the unconditional probability of those firms is $0.1 \%$, the estimated semielasticity is $2 \%$. By contrast, the effect is positive in the UK and non-robust in France, since it is insignificant in specifications (4) and (5).

The results for larger firms, which are displayed in Tables 21 and 22, confirm the findings for the unweighted sample in the case of Spain: Tangibility has no impact on 
Table 19 Marginal effects (\%) for the probability of bankruptcy in micro firms (OLS) (weighted sample)

\begin{tabular}{|c|c|c|c|c|c|}
\hline & (1) & (2) & (3) & (4) & (5) \\
\hline \multicolumn{6}{|l|}{ Spain } \\
\hline Tangibility & $\begin{array}{c}-0.0004 * * * \\
(0.0000)\end{array}$ & $\begin{array}{c}-0.0004 * * * \\
(0.0000)\end{array}$ & $\begin{array}{c}-0.0004 * * * \\
(0.0000)\end{array}$ & $\begin{array}{c}-0.0003 * * * \\
(0.0000)\end{array}$ & $\begin{array}{c}-0.0003 * * * \\
(0.0000)\end{array}$ \\
\hline Log (age) & & $\begin{array}{r}0.0209 * * * \\
(0.0042)\end{array}$ & $\begin{array}{r}0.0181 * * * \\
(0.0042)\end{array}$ & $\begin{array}{r}0.0132 * * * \\
(0.0042)\end{array}$ & $\begin{array}{r}0.0132 * * * \\
(0.0042)\end{array}$ \\
\hline $\log ($ size $)$ & & & $\begin{array}{r}0.0233 * * * \\
(0.0037)\end{array}$ & $\begin{array}{r}0.0302 * * * \\
(0.0038)\end{array}$ & $\begin{array}{r}0.0302 * * * \\
(0.0038)\end{array}$ \\
\hline Limited liability & & & & & $\begin{array}{r}0.1255^{* * * *} \\
(0.0285)\end{array}$ \\
\hline Industry dummies (1 digit) & No & No & No & Yes & Yes \\
\hline $\mathrm{N}$ & 44,189 & 44,164 & 44,164 & 44,164 & 44,164 \\
\hline R-squared (\%) & 0.01 & 0.02 & 0.02 & 0.05 & 0.05 \\
\hline \multicolumn{6}{|l|}{ France } \\
\hline Tangibility & $\begin{array}{l}0.002 \\
\quad(0.006)\end{array}$ & $\begin{array}{l}0.000 \\
\quad(0.005)\end{array}$ & $\begin{array}{r}-0.000 \\
(0.006)\end{array}$ & $\begin{array}{r}-0.003 \\
(0.006)\end{array}$ & $\begin{array}{r}-0.003 \\
(0.006)\end{array}$ \\
\hline Log (age) & & $\begin{array}{r}2.774 * * * \\
(0.514)\end{array}$ & $\begin{array}{r}2.693 * * * \\
(0.530)\end{array}$ & $\begin{array}{r}2.503 * * * \\
(0.596)\end{array}$ & $\begin{array}{r}2.492 * * * \\
(0.596)\end{array}$ \\
\hline $\log ($ size $)$ & & & $1.365^{*}(0.734)$ & $0.256(0.696)$ & $0.225(0.691)$ \\
\hline Limited liability & & & & & $\begin{array}{r}7.481 * * * \\
(2.653)\end{array}$ \\
\hline Industry dummies (1 digit) & No & No & No & Yes & Yes \\
\hline $\mathrm{N}$ & 42,408 & 42,405 & 42,405 & 42,405 & 42,405 \\
\hline R-squared (\%) & 0.00 & 0.37 & 0.45 & 1.24 & 1.28 \\
\hline \multicolumn{6}{|l|}{ UK } \\
\hline Tangibility & $\begin{array}{r}0.077 * * * \\
(0.014)\end{array}$ & $\begin{array}{r}0.082 * * * \\
(0.014)\end{array}$ & $\begin{array}{r}0.074 * * * \\
(0.014)\end{array}$ & $\begin{array}{r}0.076^{* * * *} \\
(0.013)\end{array}$ & $\begin{array}{r}0.076 * * * \\
(0.013)\end{array}$ \\
\hline Log (age) & & $\begin{array}{c}-4.736 * * \\
(1.877)\end{array}$ & $\begin{array}{c}-4.046 * * \\
(1.847)\end{array}$ & $\begin{array}{c}-5.770 * * * \\
(1.734)\end{array}$ & $\begin{array}{c}-5.779 * * * \\
(1.736)\end{array}$ \\
\hline $\log ($ size $)$ & & & $\begin{array}{c}19.456 * * * \\
(2.589)\end{array}$ & $\begin{array}{c}16.195 * * * \\
(2.460)\end{array}$ & $\begin{array}{c}16.167 * * * \\
(2.483)\end{array}$ \\
\hline Limited liability & & & & & $5.229(4.774)$ \\
\hline Industry dummies (1digit) & No & No & No & Yes & Yes \\
\hline $\mathrm{N}$ & 2,041 & 2,041 & 2,041 & 2,041 & 2,041 \\
\hline R-squared (\%) & 2.51 & 2.94 & 7.03 & 12.4 & 12.41 \\
\hline
\end{tabular}

Dependent variable: Bankruptcy. Unconditional probabilities = 0.1\% (Spain), $12.4 \%$ (France), $36.5 \%$ (UK). All regressions include a constant. Sampling weights are used. Estimator: OLS. Robust standard errors in parentheses. *, **, and ***, significant at 10,5 , and $1 \%$ level

the probability of bankruptcy, since it is not statistically different from zero in any IV estimation. By contrast, the effect is positive in the UK-as it was in the unweighted sample - and non-robust in France, since it is insignificant in the IV estimation of specifications (4) and (5), unlike the unweighted case. An interpretation of the contradictory results for France is that the associations between the two variables found in 


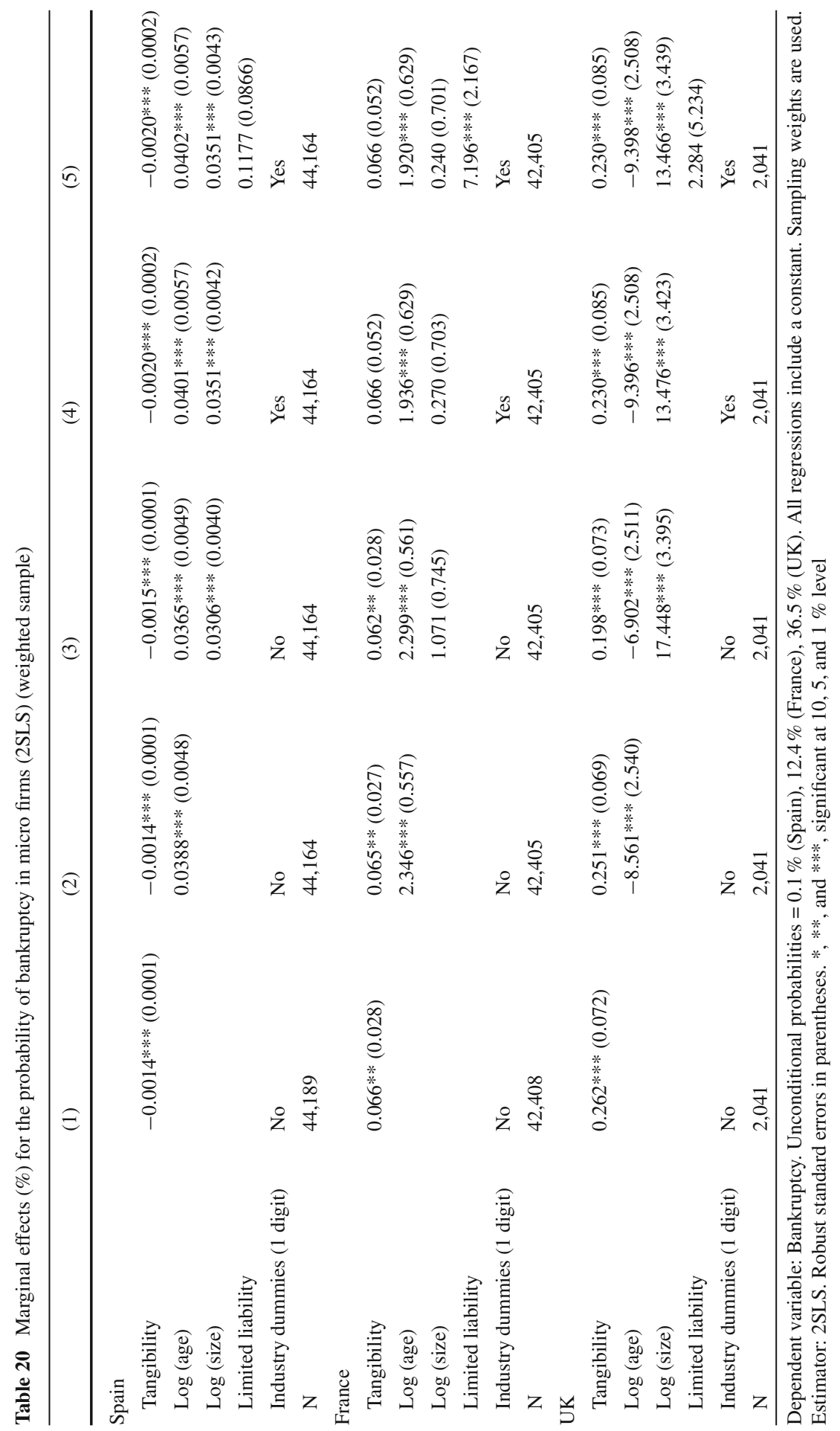


Table 21 Marginal effects (\%) for the probability of bankruptcy in non-micro firms (OLS) (weighted sample)

\begin{tabular}{|c|c|c|c|c|c|}
\hline & (1) & (2) & (3) & (4) & $(5)$ \\
\hline \multicolumn{6}{|l|}{ Spain } \\
\hline Tangibility & $\begin{array}{c}-0.0028 * * * \\
(0.0002)\end{array}$ & $\begin{array}{c}-0.0029 * * * \\
(0.0003)\end{array}$ & $\begin{array}{c}-0.0027 * * * \\
(0.0003)\end{array}$ & $\begin{array}{c}-0.0027 * * * \\
(0.0003)\end{array}$ & $\begin{array}{c}-0.0027 * * * \\
(0.0003)\end{array}$ \\
\hline Log (age) & & $\begin{array}{r}0.2356^{* * * *} \\
(0.0483)\end{array}$ & $\begin{array}{r}0.1707 * * * \\
(0.0489)\end{array}$ & $\begin{array}{l}0.1183 * * \\
(0.0516)\end{array}$ & $\begin{array}{l}0.1210 * * \\
\quad(0.0517)\end{array}$ \\
\hline $\log ($ size $)$ & & & $\begin{array}{r}0.3587 * * * \\
(0.0528)\end{array}$ & $\begin{array}{r}0.3242 * * * \\
(0.0532)\end{array}$ & $\begin{array}{r}0.3266^{* * * *} \\
(0.0533)\end{array}$ \\
\hline Limited liability & & & & & $\begin{array}{r}1.5896 * * * \\
(0.3846)\end{array}$ \\
\hline Industry dummies (1 digit) & No & No & No & Yes & Yes \\
\hline $\mathrm{N}$ & 10,291 & 10,285 & 10,285 & 10,285 & 10,285 \\
\hline R-squared (\%) & 0.08 & 0.10 & 0.17 & 0.32 & 0.32 \\
\hline \multicolumn{6}{|l|}{ France } \\
\hline Tangibility & $\begin{array}{r}-0.004 \\
(0.008)\end{array}$ & $\begin{array}{c}-0.005 \\
(0.008)\end{array}$ & $\begin{array}{r}-0.003 \\
(0.008)\end{array}$ & $\begin{array}{r}-0.014 * \\
(0.008)\end{array}$ & $\begin{array}{r}-0.014 * \\
(0.008)\end{array}$ \\
\hline Log (age) & & $\begin{array}{r}2.381 * * \\
(1.012)\end{array}$ & $\begin{array}{r}2.972 * * * \\
(1.065)\end{array}$ & $1.753(1.164)$ & $1.735(1.172)$ \\
\hline $\log ($ size $)$ & & & $\begin{array}{c}-3.198 * * * \\
(1.190)\end{array}$ & $\begin{array}{c}-3.979 * * * \\
(1.272)\end{array}$ & $\begin{array}{c}-3.955^{* * * *} \\
(1.289)\end{array}$ \\
\hline Limited liability & & & & & $1.006(3.131)$ \\
\hline Industry dummies (1 digit) & No & No & No & Yes & Yes \\
\hline $\mathrm{N}$ & 14,790 & 14,790 & 14,790 & 14,790 & 14,790 \\
\hline R-squared (\%) & 0.01 & 0.25 & 0.73 & 5.58 & 5.58 \\
\hline \multicolumn{6}{|l|}{ UK } \\
\hline Tangibility & $\begin{array}{r}0.123 * * * \\
(0.009)\end{array}$ & $\begin{array}{r}0.130 * * * \\
(0.008)\end{array}$ & $\begin{array}{r}0.126^{* * * *} \\
(0.008)\end{array}$ & $\begin{array}{r}0.121 * * * \\
(0.009)\end{array}$ & $\begin{array}{r}0.120 * * * \\
(0.009)\end{array}$ \\
\hline Log (age) & & $\begin{array}{c}-8.705^{* * * *} \\
(1.373)\end{array}$ & $\begin{array}{c}-6.595 * * * \\
(1.421)\end{array}$ & $\begin{array}{c}-8.139 * * * \\
(1.326)\end{array}$ & $\begin{array}{c}-8.113 * * * \\
(1.328)\end{array}$ \\
\hline $\log ($ size $)$ & & & $\begin{array}{c}-7.449 * * * \\
(0.606)\end{array}$ & $\begin{array}{c}-7.478 * * * \\
(0.572)\end{array}$ & $\begin{array}{c}-7.440 * * * \\
(0.573)\end{array}$ \\
\hline Limited liability & & & & & $\begin{array}{c}17.422 * * * \\
(3.895)\end{array}$ \\
\hline Industry dummies (1 digit) & No & No & No & Yes & Yes \\
\hline $\mathrm{N}$ & 7,589 & 7,589 & 7,589 & 7,589 & 7,589 \\
\hline R-squared (\%) & 6.24 & 8.15 & 10.27 & 13.55 & 13.57 \\
\hline
\end{tabular}

Dependent variable: Bankruptcy. Unconditional probabilities $=1.1 \%$ (Spain), 17.9\% (France), 37.7\% (UK). All regressions include a constant. Sampling weights are used. Estimator: OLS. Robust standard errors in parentheses. *,**, and ***, significant at 10,5 , and $1 \%$ level

the unweighted sample were driven by some observations that were overrepresented in such a sample. 
Table 22 Average marginal effects (\%) for the probability of bankruptcy in non-micro firms (2SLS) (weighted sample)

\begin{tabular}{|c|c|c|c|c|c|}
\hline & (1) & (2) & (3) & (4) & (5) \\
\hline \multicolumn{6}{|l|}{ Spain } \\
\hline Tangibility & $\begin{array}{l}-0.0015 \\
(0.0012)\end{array}$ & $\begin{array}{l}-0.0019 \\
(0.0012)\end{array}$ & $\begin{array}{l}-0.0013 \\
(0.0013)\end{array}$ & $\begin{array}{l}-0.0014 \\
(0.0016)\end{array}$ & $\begin{array}{l}-0.0014 \\
(0.0016)\end{array}$ \\
\hline Log (age) & & $\begin{array}{l}0.2211 * * * \\
(0.0493)\end{array}$ & $\begin{array}{l}0.1491 * * * \\
(0.0505)\end{array}$ & $\begin{array}{l}0.1005^{*} \\
(0.0553)\end{array}$ & $\begin{array}{l}0.1034 * \\
(0.0554)\end{array}$ \\
\hline $\log ($ size $)$ & & & $\begin{array}{l}0.3703 * * * \\
(0.0541)\end{array}$ & $\begin{array}{l}0.3342 * * * \\
(0.0546)\end{array}$ & $\begin{array}{l}0.3365 * * * \\
(0.0547)\end{array}$ \\
\hline Limited liability & & & & & $\begin{array}{l}1.5948 * * * \\
(0.3635)\end{array}$ \\
\hline $\begin{array}{l}\text { Industry dummies } \\
\text { (1 digit) }\end{array}$ & No & No & No & Yes & Yes \\
\hline $\mathrm{N}$ & 10,291 & 10,285 & 10,285 & 10,285 & 10,285 \\
\hline \multicolumn{6}{|l|}{ France } \\
\hline Tangibility & $\begin{array}{l}0.092 * * \\
(0.038)\end{array}$ & $\begin{array}{l}0.096 * * \\
(0.037)\end{array}$ & $\begin{array}{l}0.098 * * * \\
(0.037)\end{array}$ & $\begin{array}{l}0.066 \\
(0.048)\end{array}$ & $\begin{array}{l}0.068 \\
(0.048)\end{array}$ \\
\hline Log (age) & & $\begin{array}{l}1.841 \\
(1.125)\end{array}$ & $\begin{array}{l}2.508 * * \\
(1.178)\end{array}$ & $\begin{array}{l}1.202 \\
(1.272)\end{array}$ & $\begin{array}{l}1.158 \\
(1.288)\end{array}$ \\
\hline $\log ($ size $)$ & & & $\begin{array}{l}-3.632 * * * \\
(1.167)\end{array}$ & $\begin{array}{l}-4.226^{* * *} \\
(1.236)\end{array}$ & $\begin{array}{l}-4.180^{* * *} \\
(1.253)\end{array}$ \\
\hline Limited liability & & & & & $\begin{array}{l}2.058 \\
(3.315)\end{array}$ \\
\hline $\begin{array}{l}\text { Industry dummies } \\
\text { (1 digit) }\end{array}$ & No & No & No & Yes & Yes \\
\hline $\mathrm{N}$ & 14,790 & 14,790 & 14,790 & 14,790 & 14,790 \\
\hline \multicolumn{6}{|l|}{ UK } \\
\hline Tangibility & $\begin{array}{l}0.280 * * * \\
(0.049)\end{array}$ & $\begin{array}{l}0.272 * * * \\
(0.046)\end{array}$ & $\begin{array}{l}0.253 * * * \\
(0.047)\end{array}$ & $\begin{array}{l}0.218 * * * \\
(0.036)\end{array}$ & $\begin{array}{l}0.218 * * * \\
(0.036)\end{array}$ \\
\hline Log (age) & & $\begin{array}{l}-10.398 * * * \\
(1.637)\end{array}$ & $\begin{array}{l}-8.321 * * * \\
(1.705)\end{array}$ & $\begin{array}{l}-9.536^{* * *} \\
(1.391)\end{array}$ & $\begin{array}{l}-9.516^{* * *} \\
(1.393)\end{array}$ \\
\hline $\log ($ size $)$ & & & $\begin{array}{l}-6.712 * * * \\
(0.582)\end{array}$ & $\begin{array}{l}-6.892 * * * \\
(0.606)\end{array}$ & $\begin{array}{l}-6.869^{* * * *} \\
(0.605)\end{array}$ \\
\hline Limited liability & & & & & $\begin{array}{l}11.349 * * \\
(4.984)\end{array}$ \\
\hline $\begin{array}{l}\text { Industry dummies } \\
\text { (1 digit) }\end{array}$ & No & No & No & Yes & Yes \\
\hline $\mathrm{N}$ & 7,589 & 7,589 & 7,589 & 7,589 & 7,589 \\
\hline
\end{tabular}

Dependent variable: Bankruptcy. Unconditional probabilities $=12.8 \%$ (Spain), $18.2 \%$ (France), $29.5 \%$ (UK). All regressions include a constant. Sampling weights are used. Estimator: 2SLS. Robust standard errors in parentheses. *, **, and $* * *$, significant at 10,5 , and $1 \%$ level 


\section{References}

Altman E (2000) Predicting financial distress of companies: revisiting the Z-score and ZETA models. (The paper is adapted and updated from Altman E (1968) Financial ratios, discriminant analysis and the prediction of corporate bankruptcy. J Financ September 1968; and Altman E, Haldeman R, Narayanan P (1977) Zeta analysis: a new model to identify bankruptcy risk of corporations. J Bank Financ 1, 1977)

Acharya VV, Sundaram RK, John K (2011) Cross-country variations in capital structures: the role of bankruptcy codes. J Financ Intermed 20(1):25-54

Altares (2011) Bilan 2010: défaillances et sauvegardes d'entreprises en France, Altares

Armour J (2001) The law and economics of corporate insolvency: a review, ESRC Centre for Business Research, University of Cambridge Working paper no 197

Armour J, Hsu A (2012) The costs and benefits of secured creditor control in bankruptcy: evidence from the UK. Rev Law Econ 8:1

Angrist JD, Pischke J-S (2009) Mostly harmless econometrics: an empiricist's companion, Princenton University Press, Princenton

Ayotte K, Yun H (2009) Matching bankruptcy laws to legal environments. J Law Econ Org 25(1):2-30

Berger A, Udell G (1995) Relationship lending and lines of credit in small firm finance. J Bus 68:351-381

Berkowitz J, White M (2004) Bankruptcy and small firms' access to credit. Rand J Econ 35(1):69-84

Blazy R, Chopard B, Eric L, Ziane Y (2011) Personal bankruptcy law, fresh start and judicial practice. Available at SSRN: http://ssrn.com/abstract=1784703

Bolton P, Scharfstein D (1996) Optimal debt structure and the number of creditors. J Polit Econ 104:1-25

Brown M, Forsythe A (1974) Robust tests for the equality of variances. J Am Stat Assoc 69:364-367

Celentani M, García-Posada M, Gómez F (2010) The Spanish business bankruptcy puzzle and the crisis, FEDEA working paper 2010-11

Celentani M, García-Posada M, Gómez F (2012) The Spanish business bankruptcy puzzle, mimeo

Consejo General del Poder Judicial (2012) Datos sobre el efecto de la crisis en los organos judiciales: Cuarto trimestre de 2012

Consejo General del Poder Judicial (2011) La Justicia Dato a Dato. Año 2011. Estadística Judicial

Davydenko S A, Franks JR (2008) Do bankruptcy codes matter? A study of defaults in France, Germany, and the UK. J Financ vol LXIII, no 2, April 2008

Djankov S, McLiesh C (2007) Private credit in 129 countries. J Financ Econ 84:299-329

Djankov S, Hart O, McLiesh C, Shleifer A (2008) Debt enforcement around the world. J Polit Econ vol 116(6):1105-1149

Hermes E (2007) Insolvency outlook 2007, no 2, Business insolvency worlwide. Euler Hermes, Evreux

Hermes Euler (2011) Economic outlook 2011, no 4, Business insolvency worlwide. Euler Hermes, Evreux

European Mortgage Federation (2007) Study on the efficiency of the mortgage collateral in the European union, EMF Publication, May 2007

Fabbri D (2010) Law enforcement and firm financing: theory and evidence. J Eur Econ Assoc 8(4):776-816

Franks J, Sussman O (2005) Financial distress and bank restruc-turing of small and medium size UK companies. Rev Financ 9(March):65-96

Frisby S (2006) Report on insolvency outcomes. The insolvency service report, UK

García-Posada M, Mora-Sanguinetti JS (2012) Why do Spanish firms rarely use the bankruptcy system? The role of the mortgage institution. Working paper 1234 Banco de España Working Papers, no 1234

García-Posada, M (2013) Insolvency institutions and efficiency: the Spanish case, Banco de España Working papers, no 1302

Gilson S, John K, Lang L (1990) Troubled debt restructurings: an empirical study of private reorganization of firms in default. J Financ Econ 27(October):315-353

Grice J, Ingram R (2001) Tests of the generalizability of Altman's bankruptcy prediction model. J Bus Res 54:53-61

Gutiérrez M (2005) Los procedimientos concursales como instituciones de gobierno corporativo. Anuario de Derecho Concursal 6:307-328

Hernández-Cánovas G, Köeter-Kant J (2008) The institutional environment and the number of bank relationships: an empirical analysis of European SMEs. Small Bus Econ 34:375-390

La Porta R, Lopez de Silanes F, Shleifer A, Vishny RW (1998) Law and finance. J Polit Econ 106:1113-1155

Ministère de la Justice (2010) Annuarie statistique de la Justice Édition 2009-2010

Morrison E (2008) Bankruptcy's rarity: an essay on small business bankruptcy in the United States. In: Proceedings from the second ECFR symposium on corporate insolvency (October 2007), pp 172-188 
Morrison E (2009) Bargaining around Bankruptcy: small business distress and state law. J Legal Stud vol 38(2):255-307

Murray ZF, Vidhan KG (2008) Trade-off and pecking order theories of debt. In: Espen Eckbo B (ed) Handbook of corporate finance: Empirical Corporate Finance, vol 2, Handbooks in finance series, Elsevier, North-Holland, Ch 12

Observatory of European SMEs (2003) SMEs in Europe 2003

Petersen M, Rajan R (1994) The benefits of lending relationships: evidence from small business data. J Financ XLIX(1):3-37

Ponticelli J (2012) Court enforcement and firm productivity: evidence from a bankruptcy reform in Brazil. Available at SSRN: http://ssrn.com/abstract=2179022

Ragoussis A, Gonnard E (2011) The OECD-ORBIS database treatment and benchmarking procedures, mimeo. OECD Publishing, Paris

Registradores de España (2012) Panorama Registral: Impagos hipotecarios de vivienda

Ribeiro, Menghinello, De Backer (2010) The OECD ORBIS database: responding to the need for firm-level micro-data in the OECD. OECD working paper no 30-2010/1

Ross, Westerfield, Jaffe (2005) Corporate finance, 7th edn, McGraw-Hill, Irwin

Van Hemmen E (2004) Análisis institucional y económico de la nueva Ley Concursal, Estabilidad Financiera, no 6:189-210

Van Hemmen E (2008) Estadística concursal. Anuario 2007. Colegio de Registradores de la Propiedad y Mercantiles de España, Madrid

Van Hemmen E (2011) Estadística concursal. Anuario 2010. Colegio de Registradores de la Propiedad y Mercantiles de España, Madrid

Van Hemmen E (2012) Estadística concursal. Anuario 2011. Colegio de Registradores de la Propiedad y Mercantiles de España, Madrid

Wooldridge J (2002) Econometric analysis of cross section and panel data, MIT Press 